Hepat i c I SG expressi on is associ at ed wi th genet i c vari at i on i $n$ i nt erl euki $n 28 \mathrm{~B}$ and the out come of I FN therapy for chroni c hepat i t i s C

\begin{tabular}{|c|c|}
\hline 著者 & $\begin{array}{l}\text { Honda Nasao, Sakai Aki to, Yamashi ta Tat suya, } \\
\text { Nakamøt oa Yasunar i, M zukoshi Ei shi ro, Sakai } \\
\text { Yoshi o, Yamashi t a Tar o, Nakamur a M ki ko, } \\
\text { Shi rasaki Takayoshi, Hor i mot o Kat suhi sa, } \\
\text { Tanaka Yasuhi to, Tokunaga Kat sushi, M zokam } \\
\text { Masashi, Kaneko Shui chi, Hokur i ku Li ver St udy } \\
\text { Group }\end{array}$ \\
\hline $\begin{array}{l}\mathrm{j} \text { our nal or } \\
\text { publ i cat } \mathrm{i} \text { on } \mathrm{title}\end{array}$ & Gast r oent er ol ogy \\
\hline vol une & 139 \\
\hline number & 2 \\
\hline page $r$ ange & $499-509$ \\
\hline year & 2010-08-01 \\
\hline URL & ht t p: //hdl . handl e. net /2297/25264 \\
\hline
\end{tabular}




\title{
Hepatic ISG expression is associated with genetic variation in IL28B and the outcome of IFN therapy for chronic hepatitis $C$
}

Running title: Hepatic expression of ISGs and IFN therapy

\begin{abstract}
Masao Honda) ${ }^{1)}$, Akito Sakai ${ }^{1)}$, Tatsuya Yamashita ${ }^{1)}$, Yasunari Nakamoto ${ }^{1)}$, Eishiro Mizukoshi ${ }^{1)}$, Yoshio Sakai ${ }^{1)}$, Taro Yamashita ${ }^{1)}$, Mikiko Nakamura' ${ }^{1)}$, Takayoshi Shirasaki ${ }^{2)}$, Katsuhisa Horimoto $^{3)}$, Yasuhito Tanaka ${ }^{4)}$, Katsushi Tokunaga ${ }^{5)}$, Masashi Mizokami ${ }^{4)}$, Shuichi Kaneko ${ }^{1)}$ and Hokuriku Liver Study Group*
\end{abstract}

1) Department of Gastroenterology, Kanazawa University Graduate School of Medicine, Kanazawa, Japan

2) Department of Advanced Medical Technology, Kanazawa University Graduate School of Health Medicine, Kanazawa, Japan

3) Biological Network Team, Computational Biology Research Center, National Institute of Advanced Industrial Science and Technology, Japan

4) Department of Clinical Molecular Informative Medicine, Nagoya City University Graduate School of Medicine, Nagoya, Japan

5) Department of Human Genetics, Graduate School of Medicine, The University of Tokyo, Tokyo, Japan

${ }^{*}$ Participating investigators are listed in Appendix A.

The authors declare that no potential competing interests exist.

Abbreviations: $\mathrm{CH}-\mathrm{C}$, Chronic Hepatitis C; HCV, Hepatitis C Virus; IFN, Interferon; IL, Interleukin; ISDR, Interferon Sensitivity Determining Region; ISGs, Interferon Stimulated Genes; RBV, Ribavirin; SNP, Single Nucleotide Polymorphism 
Each author was involved with the manuscript as follows:

Masao Honda) 2): analysis and interpretation of data; drafting of the manuscript

Akito Sakai ${ }^{11}$ : acquisition of data

Tatsuya Yamashita ${ }^{1)}$ : acquisition of data

Yasunari Nakamoto ${ }^{1)}$ : critical revision of the manuscript for important intellectual content

Eishiro Mizukoshi ${ }^{1)}$ : acquisition of data

Yoshio Sakai ${ }^{1)}$ : acquisition of data

Taro Yamashita ${ }^{1)}$ : acquisition of data

Mikiko Nakamura): technical support

Takayoshi Shirasaki ${ }^{2)}$ : technical support

Katsuhisa Horimoto ${ }^{3)}$ : statistical analysis of clinical data and gene expression

Yasuhito Tanaka ${ }^{4)}$ : acquisition of data of genetic variation of IL28B

Katsushi Tokunaga): acquisition of data of genetic variation of IL28B

Masashi Mizokami ${ }^{4)}$ : acquisition of data of genetic variation of IL28B

Shuichi Kaneko ${ }^{1)}$ : study concept and design

Corresponding author:

Shuchi kaneko, M.D., Ph.D.

Department of Gastroenterology, Graduate School of Medicine, Kanazawa University,

Takara-Machi 13-1, Kanazawa 920-8641, Japan

Tel: +81-76-265-2235; Fax: +81-76-234-4250

E-mail: skaneko@m-kanazawa.jp 


\section{Abstract}

Objective: Multiple viral and host factors are related to the treatment response to pegylated-interferon (Peg-IFN) and ribavirin (RBV) combination therapy; however, the clinical relevance and relationship of these factors have not yet been fully evaluated.

Methods: We studied 168 patients with chronic hepatitis C who received Peg-IFN and RBV combination therapy. Gene expression profiles in the livers of 91 patients were analyzed using an Affymetrix genechip. The expression of interferon-stimulated genes (ISGs) was evaluated in all samples by real-time PCR. Genetic variation in interleukin 28B (IL28B; rs8099917) was determined in 91 patients.

Results: Gene expression profiling of the liver differentiated patients into two groups: patients with up-regulated ISGs (Up-ISGs) and patients with down-regulated ISGs (Down-ISGs). A high proportion of patients with no response (NR) to treatment was found in the Up-ISGs group $(p=0.002)$. Multivariate logistic regression analysis showed that ISGs $(<3.5)$ (Odds $=16.2, p<0.001)$, fibrosis stage $(F 1-2)($ Odds $=4.18, p=0.003)$, and ISDR mutation $(\geqq 2)$ (Odds $=5.09, p=0.003$ ) were strongly associated with the viral response. The IL28B polymorphism of 91 patients showed that $66 \%$ were major homozygotes (TT), 30\% were heterozygotes (TG), and 4\% were minor homozygotes (GG). Interestingly, hepatic ISGs were associated with the IL28B polymorphism (Odds $=18.1, \mathrm{p}<0.001)$ and its expression was significantly higher in patients with the minor genotype (TG or $G G$ ) than in those with the major genotype (TT).

Conclusions: The expression of hepatic ISGs is strongly associated with treatment response and genetic variation of IL28B. The differential role of host and viral factors as predicting factors may also be present.

Keywords: Pegylated interferon, Ribavirin, Gene expression, Single Nucleotide Polymorphism 


\section{Introduction}

A human liver infected with hepatitis C virus (HCV) develops chronic hepatitis, cirrhosis, and in some instances, hepatocellular carcinoma (HCC). ${ }^{1}$ Interferon (IFN) and ribavirin (RBV) combination therapy is a popular modality for treating patients with chronic hepatitis $\mathrm{C}(\mathrm{CH}-\mathrm{C})$; approximately $50 \%$ of patients usually relapse, particularly those with $\mathrm{HCV}$ genotype $1 \mathrm{~b}$ and a high viral load. ${ }^{2,3}$ Therefore, it is beneficial to predict the response of patients with the $1 \mathrm{~b}$ genotype and a high viral load to polyethylene glycol-IFN (Peg-IFN) and RBV combination therapy before starting treatment because therapy can be long, costly, and have many side effects. Amino acid (aa) substitutions in the interferon sensitivity determining region (ISDR), located in the $\mathrm{HCV}$ nonstructural region $5 \mathrm{~A}$, are useful for predicting the response of patients with genotype $1 \mathrm{~b}$ to IFN therapy. ${ }^{4}$ However, viral factors alone do not sufficiently predict the outcome of treatment in every case. ${ }^{5}$

In addition to viral factors, hepatic gene expression before and during IFN treatment has been examined to determine host factors associated with the response to treatment. ${ }^{6,7}$ Interferon-stimulated genes (ISGs) upregulated in the liver prior to treatment might be related to the poor induction of ISGs and the impaired eradication of HCV during treatment. ${ }^{6-9}$ This may be because the ISGs have already been maximally induced before treatment. However, the clinical relevance of the expression of ISGs as predictive factors for the outcome of treatment has not yet been fully evaluated.

In parallel to gene expression analysis, genome-wide association studies (GWAS) have been used to identify loci associated with the response to treatment; genetic variation in interleukin 28B (IL28B) was found to predict hepatitis C treatment-induced viral clearance. ${ }^{10-12}$ In this study, with a relatively large cohort of $\mathrm{CH}-\mathrm{C}$ patients treated with Peg-IFN and RBV, we validated the clinical relevance of the expression of hepatic ISGs as predictive factors for the outcome of treatment. In addition, we demonstrated that the expression of hepatic ISGs was closely related to genetic variation in IL28B. 


\section{Materials and Methods}

\section{Patients}

We enrolled 168 patients with $\mathrm{CH}-\mathrm{C}$ at the Graduate School of Medicine, Kanazawa University Hospital and its related hospitals, Japan (Table 1, Supplemental Table 1). The cohort included 92 men and 76 women, ranging from 21-73 years of age, who were registered prospectively in 2005 and 2007. All patients had HCV genotype $1 \mathrm{~b}$ and high viral loads ( $\geq 100 \mathrm{KIU} / \mathrm{ml}$ ) measured by quantitative Cobas Amplicor assays (Roche Diagnostics Co. Ltd., Tokyo, Japan). All patients had undergone liver biopsy before combination therapy. Exclusion criteria for patients not eligible for Peg-IFN and RBV combination therapy were as follows: (1) pregnant women or women of child-bearing potential, nursing mothers, or male patients whose partner might become pregnant; (2) patients with hepatocellular carcinoma; (3) patients with serious complications in the heart, kidneys, or lungs; (4) patients with autoimmune diseases, such as autoimmune hepatitis, and primary biliary cirrhosis; and (5) patients infected with the hepatitis B virus. Informed consent was obtained from all patients and ethics approval for the study was obtained from the ethics committee for human genome/gene analysis research at Kanazawa University Graduate School of Medical Science.

All patients were administered Peg-IFN- $\alpha$ 2b (Schering-Plough K.K., Tokyo, Japan) and RBV combination therapy for 48 wk. Peg-IFN was given in weekly doses and adjusted to body weight according to the manufacturer's instructions (45 kg or less, $60 \mu \mathrm{g} / \mathrm{dose}$; $46-60 \mathrm{~kg}$, $80 \mu \mathrm{g} /$ dose; $61-75 \mathrm{~kg}, 100 \mu \mathrm{g} /$ dose; 76-90 kg, $120 \mu \mathrm{g} / \mathrm{dose}$; and $91 \mathrm{~kg}$ or more, $150 \mu \mathrm{g} / \mathrm{dose})$. Similarly, RBV (Schering-Plough K.K.) was administered in daily doses adjusted to body weight according to the manufacturer's instructions (60 kg or less, $600 \mathrm{mg} / \mathrm{day} ; 61-80 \mathrm{~kg}, 800$ $\mathrm{mg} /$ day; and $81 \mathrm{~kg}$ or more, 1,000 mg/day).

The final outcome of treatment was assessed 24 wk after the cessation of combination therapy. We defined treatment outcomes according to the decrease in viremia as 
follows: sustained viral response (SVR), clearance of HCV viremia 24 wk after the cessation of therapy; transient response (TR), no detectable HCV viremia at the cessation of therapy but relapsed during the follow-up period; and no response (NR), HCV viremia detected at the cessation of therapy. An early virological response (complete EVR) was defined as undetectable HCV RNA in the serum by 12 wk. HCV genotypes were determined according to the method of Ohno et al. Serum HCV RNA was determined using qualitative and quantitative COBAS Amplicor assays (Roche Diagnostics Co., Ltd., Tokyo, Japan). The grading and staging of chronic hepatitis were histologically assessed according to the method of Desmet et al. (Table 1). ${ }^{13}$

\section{Preparation of liver tissue samples}

Liver biopsy samples were taken from all patients before treatment. The biopsy samples were divided into two parts: the first part was immersed in formalin for histological assessment and the second was immediately immersed in RNAlater (QIAGEN, Valencia, CA, USA) for RNA isolation. Liver tissue RNA was isolated using the RNeasy Mini kit (QIAGEN) according to the manufacturer's instructions. Isolated RNA was stored at $-70^{\circ} \mathrm{C}$ until use.

\section{Affymetrix genechip analysis}

The quality of the isolated RNA was estimated after electrophoresis using an Agilent 2001 Bioanalyzer (Palo Alto, CA, USA). Aliquots of total RNA (50 ng) isolated from the liver biopsy specimens were subjected to amplification using the WT-Ovation Pico RNA Amplification System (NuGen, San Carlos, CA, USA) according to the manufacturer's instructions. Approximately $10 \mu \mathrm{g}$ of cDNA was amplified from $50 \mathrm{ng}$ of total RNA, and $5 \mu \mathrm{g}$ of

cDNA was used for fragmentation and biotin labeling using the FL-Ovation cDNA Biotin Module V2 (NuGen) according to the manufacturer's instructions. Biotin-labeled cDNA was suspended in $220 \mu$ of hybridization cocktail (NuGen) and $200 \mu$ l was used for hybridization to 
the Affymetrix Human 133 Plus 2.0 microarray chip containing 54,675 probes. After stringent washing, the microarray chips were stained with streptavidin-phycoerythrin and probe hybridization was determined using a GeneChip Scanner 3000 (Affymetrix). Data files (CEL) were obtained using the GeneChip Operating Software 1.4 (Affymetrix).

\section{Hierarchical clustering and pathway analysis of genechip data}

Genechip data analysis was performed using BRB-Array Tools (http://linus.nci.nih.gov/BRB-ArrayTools.htm). The data were log-transferred, normalized, centered, and applied to the average linkage hierarchical clustering with centered correlation. For genechip analysis, we selected 37 representative ISGs. Hepatic gene expression profiling was obtained from $30 \mathrm{CH}-\mathrm{C}$ patients before and one week after the initiation of IFN and RBV combination therapy and the 100 most up-regulated genes were selected (submitted for publication). ISGs were suppressed in patients with a rapid viral response and up-regulated in patients with a slow viral response before treatment. Using the 100 treatment-induced genes, we evaluated hepatic gene expression in 30 patients before treatment. Hierarchical clustering analysis showed that a cluster of 37 ISGs was up-regulated in patients with a slow viral response.

Pathway analysis was performed using MetaCore (GeneGo, St. Joseph, MI, USA). Functional ontology enrichment analysis was performed to compare the Gene Ontology (GO) process distribution of differentially expressed genes $(p<0.01)$.

\section{Quantitative real-time detection (RTD)-PCR}

We performed quantitative real-time detection PCR (RTD-PCR) using TaqMan Universal Master Mix (PE Applied Biosystems, CA, USA). Primer pairs and probes for Mx1, OAS3, IFI44, IFI44L, OAS2, USP18, RSAD2, IFIT1, IFIH1, XAF1, CMPK2, EPSTI1, HERC6, PARP9, PLSCR1, and GAPDH were obtained from the TaqMan assay reagents library. Primer 
pairs and probes for IL28B were designed as previously described. ${ }^{12}$ The standard curve was obtained in every assay using the RNA obtained from a normal liver. ${ }^{14,15}$ The expression values were normalized by GAPDH and normalized values indicate the relative fold expression to a normal liver.

\section{Amino acid substitutions of ISDR in the nonstructural 5A region}

The nucleotide sequence of ISDR in the nonstructural 5A region (NS5A) was determined by direct sequencing of PCR amplified materials. ${ }^{4}$ Mutant-type ISDR was defined as containing two or more aa substitutions.

\section{Genetic variation of IL28B polymorphism}

A single nucleotide polymorphism (SNP) of IL28B was evaluated in 91 patients whose hepatic gene expression profiling was obtained. We genotyped 32 patients using Affymetrix Genome-Wide Human SNP Array 6.0 as previously described. ${ }^{12}$ The results for rs8105790, rs11881222, rs8099917, and rs7248668 were retrieved from a database to evaluate the association of these SNPs. rs $12979860^{11}$ was determined by direct sequencing and rs8099917 was determined using TaqMan® Pre-Designed SNP Genotyping Assays as recommended by the manufacturer.

\section{Statistical analysis}

The Mann-Whitney U-test was used to analyze continuous variables. Chi-squared and Fisher's exact tests were used for the analysis of categorical data.

The overall plausibility of the treatment response groups was assessed using Fisher's C statistic (Supplemental Table 2). ${ }^{16,17} \mathrm{C}$ is defined by $\mathrm{C}=-2 \Sigma \ln \left(p_{\mathrm{i}}\right)$, where $p_{\mathrm{i}}$ is the probability ( $p$-value) of each independent statement (clinical factors). C follows a chi-square distribution with $2 \mathrm{k}$ degrees of freedom, $\mathrm{k}$ being the number of independent statements

(clinical factors). ${ }^{16} \mathrm{~A}$ non-significant $\mathrm{C}$ value means that the treatment response in the two 
groups was not statistically independent.

Multivariate analysis was performed using a stepwise logistic regression model. Each cut-off point for the continuous variables was decided by analysis of the receiver operating characteristic $(\mathrm{ROC})$ curve. A p-value of less than 0.05 was considered significant. Statistical analyses were performed using JMP7 for Windows (SAS Institute, Cary, NC, USA) 


\section{Results}

\section{Response rate and clinical characteristics}

The clinical characteristics of the patients are shown in Table 1 and Supplemental Table 1. All of the patients were infected with HCV genotype $1 \mathrm{~b}$ and had a high viral load $(>100 \mathrm{IU} / \mathrm{ml})$. No patients were co-infected with the hepatitis B virus (HBV). The intention-to-treat analysis showed that SVR, TR, and NR were observed in 70 (42\%), 55 (33\%), and $43(25 \%)$ patients, respectively (Supplemental Table 1). Before comparing patients with three different responses, the overall plausibility of the treatment response groups was assessed using Fisher's $C$ statistic. Fisher's $C$ statistic utilizes the p-values obtained by comparing pretreatment factors including age, gender, liver factors, laboratory parameters, and viral factors. As the SVR and TR groups could not be defined as different, they were grouped together and compared with NR (Table 1, Supplemental Table 2).

Eleven patients with NR discontinued the therapy after 24 wk because of an insufficient effect, namely, serum HCV-RNA was still detectable at this time. The remaining patients completed 48 wk of Peg-IFN and RBV combination therapy. The administration rate of Peg-IFN with $80 \%$ or more was achieved in $67 \%$ of patients, and the administration rate of RBV with $80 \%$ or more was achieved in $60 \%$ of patients (Table 1 ).

\section{Analysis of hepatic gene expression}

Prior to treatment, 91 of 168 patients (Supplemental Table 3) were randomly selected and their hepatic gene expression was determined using Affymetrix genechip analysis.

Hierarchical clustering using 37 representative ISGs (see Materials and Methods) demonstrated two clear clusters of patients, one was a group composed of patients with up-regulated ISGs (Up-ISGs) and the other was a group consisting of patients with down-regulated ISGs (Down-ISGs) (Fig. 1). In patients with Up-ISGs, 21 (49\%) showed NR, 
while $8(17 \%)$ patients with Down-ISGs showed NR ( $p=0.002)$. In contrast, $14(33 \%)$ patients with Up-ISGs showed SVR, while 27 (56\%) patients with Down-ISGs showed SVR ( $p=0.03)$. There were no significant differences in the frequency of advanced stages of liver fibrosis (F3-4) between patients with Up-ISGs and patients with Down-ISGs (18 (42\%) and 17 (35\%), respectively; $p=0.664)$. These data indicated that the up-regulation of ISGs in the liver before treatment was strongly associated with resistance to IFN treatment.

\section{Host and viral factors associated with the response to combination therapy}

To evaluate the multiple host and viral factors associated with the response to Peg-IFN and RBV combination therapy in all patients, univariate and multivariate analyses were performed. To assess the expression of hepatic ISGs, 15 genes (Mx1, OAS3, IFI44, IFI44L, OAS2, USP18, RSAD2, IFIT1, IFIH1, XAF1, CMPK2, EPSTI1, HERC6, PARP9, and PLSCR1) out of 37 representative ISGs were selected for their expression values of probe intensity and their expression was confirmed in liver tissue obtained from 168 patients by RTD-PCR. Although there were significant correlations of their expression with each other, except RARP9 and PLSCR1 (Supplemental Table 4), the dynamic range of gene expression was high for three genes, namely, myxovirus (influenza virus) resistance 1 interferon-inducible protein p78 (mouse) (Mx1), interferon-induced protein 44 (IFI44), and interferon-induced protein with tetratricopeptide repeats 1 (IFIT1) (Supplemental Fig. 1A). We averaged the expression values of Mx1, IFI44, and IFIT1 and used them for further study.

When we compared patients with SVR+TR and NR, the fibrosis stage of the liver $(p=0.001)$, expression of hepatic ISGs $(p<0.001)$, AST serum level $(p=0.017), y-G T P$ $(p<0.001)$, LDL-Chol $(p=0.019)$, and insulin $(\mu \mathrm{U} / \mathrm{ml})(p=0.039)$ were significantly different prior to treatment (Table 1). For treatment factors, the total dose and administration of IFN and RBV were not significantly different between these two groups. Early viral response (EVR) was observed in 101 (81\%) patients and the proportion was significantly different $(p<0.001)$ 
between patients with SVR+TR and NR (Table 1).

Regression analysis of pretreatment factors showed a strong correlation among Y-GTP, ALT and AST, and HOMA-IR, FBS and insulin, and T-Chol, HDL-Chol, and LDL-Chol (data not shown). We selected fibrosis stage, ISGs, HCV-RNA, ISDR mutation, and BMI as factors for multivariate analysis. Stepwise multivariate logistic regression analysis was performed using the selected factors. From the ROC curve, we set the cut-off value for the expression of ISGs as 3.5 (Supplemental Fig. 1B). The results showed that expression of hepatic ISGs $(<3.5)$, fibrosis stage $(F 1-2)$, and ISDR mutation $(\geqq 2)$ were significant pretreatment factors contributing to SVR+TR (Table 1).

\section{Clinical parameters associated with the expression of hepatic ISGs}

Univariate and multivariate analyses revealed that the expression of hepatic ISGs was a strong predictor of the treatment outcome for SVR+TR patients. We next examined which clinical parameters were associated with the expression of hepatic ISGs (Table 2). Univariate analysis showed that the expression of ISGs was strongly correlated with the serum levels of $\mathrm{y}$-GTP $(p<0.001)$ and AST $(p<0.001)$, and weakly correlated with HCV-RNA, fasting blood sugar (FBS), insulin, HOMA-IR, triglyceride (TG), and LDL-Chol. Multivariate analysis showed that $\mathrm{y}$-GTP $(p<0.001)$, HCV-RNA $(p<0.001)$, and LDL-Chol $(p=0.048)$ were significantly associated with hepatic ISGs. Noticeably, the expression of ISGs was negatively correlated with HCV-RNA in SVR+TR patients $(p=0.009)$, while this correlation was not evident in NR patients ( $p=0.298$ ) (Table 2, Supplemental Fig. 2). These results may indicate that endogenous ISGs suppress HCV in SVR+TR patients, while they are not active in NR patients.

Expression of Hepatic ISGs before treatment is associated with genetic variation of 


\section{IL28B}

Recently, a GWAS successfully identified the genomic locus associated with the treatment response to Peg-IFN and RVB combination therapy for $\mathrm{CH}-\mathrm{C}$. Genetic variation in IL28B predicts HCV treatment-induced viral clearance. ${ }^{11-12}$ We determined the genetic variation in IL28B of 32 patients $^{12}$ (Table 3). The SNPs rs8105790, rs11881222, rs8099917, and rs7248668 had a significant association with treatment response (odds ratio: 24.7-27.1, $\mathrm{p}=1.84 \times 10^{-30}-2.68 \times 10^{-32}$ ). These SNPs are located in block 2 of the IL28B haplotype and show significant linkage disequilibrium in the HapMap data. ${ }^{12}$ Ge et al. ${ }^{11}$ reported a different SNP (rs12979860) that was located between rs11881222 and rs8099917. The nucleotide sequence of rs12979860 was determined by direct sequencing and the results are shown in Table 3. There was a strong association of rs12979860 and the other four SNPs indicating that this SNP was located within the same haplotype block. We confirmed these findings in multiple samples from Japanese patients (data not shown).

We selected rs8099917 for further study and evaluated it using TaqMan® Pre-Designed SNP Genotyping Assays. The G nucleotide of rs8099917 was associated with a poor response to treatment (minor allele), while the $\mathrm{T}$ was associated with a fair response to treatment (major allele). ${ }^{12}$ Out of 91 patients (Supplemental Table 3), the proportion of major homozygotes (TT), heterozygotes (TG), and minor homozygotes (GG) were $66 \%(60 / 91)$, $30 \%(27 / 91)$, and $4 \%(4 / 91)$, respectively (Table 4$) ; 86 \%(51 / 60)$ of the major genotype (TT) patients had SVR or TR, while 65\% (20/31) with the minor genotypes (TG or GG) had NR $(p<0.001)$

Interestingly, hepatic gene expression profiles revealed that patients with the minor genotype showed higher expression of hepatic ISGs; while patients with the major genotype showed lower expression of hepatic ISGs (Figs. 2, 3). To further examine the relationship of the genetic variation in IL28B and its expression levels, we evaluated the expression of IL28B in the liver by RTD-PCR (Fig. 3). IL28B expression was approximately tenfold less than the 
expression of ISGs. Although IL28B expression tended to be higher in some patients with the major genotype, there was no significant difference in IL28B expression in the liver between the major and minor genotypes (Fig. 3A). Nevertheless, the expression of ISGs was clearly high in patients with the minor genotype $(p<0.0001)$ (Fig. 3B). IL28 activates STAT1 through downstream signaling from a heterodimeric class II cytokine receptor that consists of IL-10 receptor $\beta$ (IL-10R $\beta)$ and IL-28 receptor $\alpha($ IL-28R $\alpha) .{ }^{18}{ }^{19}$ Therefore, we examined the correlation between the expression of IL28B and ISGs. IL28B expression correlated with the expression of ISGs $(r=0.44, p<0.001)$; however, the correlation was different according to the SNP genotype. We observed a steep-slope correlation for the minor genotype and a slow-slope correlation for the major genotype (Figs. 3C, D). Interestingly, four minor homozygotic (GG) patients showed a steeper correlation than the heterozygotes (TG) (Fig. 3D). Thus, the IL28B polymorphism might differentially regulate the expression of ISGs in the liver, leading to the different treatment outcomes.

We performed univariate and multivariate analyses to identify the clinical factors associated with the major and minor genotypes (Table 4). Univariate analysis showed that higher hepatic ISGs and lower BMI were significantly associated with the minor genotype; however, multivariate analysis showed that only hepatic ISGs ( $\geqq 3.5)$ were associated with the minor genotype $(p<0.001$, Odds ratio=18.1, 95\% Cl=3.95-113). We further compared the predictive capacity of multivariate models using the expression of hepatic ISGs $(<3.5 \mathrm{vs.} \geqq$ 3.5) or the IL28B genotype (major vs. minor) (Supplemental Table 6). The predictive performance and fitness of the multivariate model using the IL28B genotype was superior to that using the expression of hepatic ISGs. However, when these factors were included in the same model, the expression of hepatic ISGs was still useful for the predictive model independent of the IL28B genotype (Supplemental Table 6).

To further examine the different hepatic gene expression of patients with the major or 
minor genotypes, pathway analysis of differentially expressed genes between the two groups was performed. By comparing the expression of hepatic genes between patients with the major and minor genotypes, 1359 differentially expressed genes were identified $(p<0.01 ; 711$ genes were up-regulated with the minor genotype and 648 genes were up-regulated with the major genotype). Pathway analysis of these genes demonstrated that signaling pathways related to interferon action, apoptosis, and Wnt signaling were up-regulated in the liver of patients with the minor genotype, while B-cell-, dendritic cell-, and NK cell-related genes were up-regulated in the liver of patients with the major genotype (Supplemental Fig. 3). These results suggest that IL28B may be involved in innate and adaptive immune responses, and different anti-viral signaling pathways might be involved in the liver of patients with different SNPs. 


\section{Discussion}

Multiple viral and host factors may be related to the treatment response to Peg-IFN and RBV combination therapy. For the viral factors, a higher number of aa substitutions in the ISDR of NS5A was strongly associated with a favorable response to IFN- $\alpha$ monotherapy in patients with genotype- 1 HCV. ${ }^{4}$

Besides viral factors, host factors such as age, gender, fibrotic stage of the liver, and the presence of steatosis and insulin resistance were associated with the treatment outcome. ${ }^{20}$ Analysis of hepatic gene expression demonstrated that the up-regulation of ISGs in the liver before treatment may be related to a poor treatment response. ${ }^{6-9}$ To reveal the underlying mechanism of treatment resistance, two reports compared gene expression profiling in the liver before and during therapy, and showed that patients with up-regulated ISGs in the liver prior to treatment failed to further induce ISGs following the administration of IFN and could not eliminate $\mathrm{HCV}^{6,7}$ We performed a similar analysis and observed that these findings were more evident in liver lobular cells than in infiltrating lymphocytes in the portal area (submitted for publication). Thus, both viral and host factors might be closely related to the treatment response to Peg-IFN and RBV combination therapy. However, the clinical relevance and relationships of these factors have not been fully evaluated. In this study, we validated the clinical significance of the expression of hepatic ISGs on treatment outcome using a relatively large cohort of patients and compared its significance with other viral and host factors. To compare the patients with SVR, TR, and NR, we assessed the overall plausibility of each group using Fisher's $\mathrm{C}$ statistic, ${ }^{16}$ and patients with SVR and TR were grouped together for further analysis.

We examined hepatic gene expression in 91 of 168 patients using the Affymetrix genechip. Expression profiling using 37 representative ISGs (see Material and Methods), which were selected from gene expression profiling comparing pretreatment and under treatment liver, differentiated two groups of patients: the Up-ISG and Down-ISG groups (Fig. 
1). The proportion of patients with NR to treatment was significantly higher in the Up-ISGs group.

Multivariate analysis showed that hepatic ISGs $(<3.5)$, fibrosis stage $(\mathrm{F} 1-2)$, and ISDR mutations ( $\geqq 2)$ significantly contributed to the outcome for the SVR+TR group (Table 1). Discriminate analysis using variables selected by multivariable analysis predicted the SVR+TR patients with $82 \%$ accuracy and NR patients with $79 \%$ accuracy. However, the accuracy decreased to $67 \%$ for SVR+TR patients and $53 \%$ for NR patients when the expression of hepatic ISGs was removed from the variables (data not shown). Interestingly, the expression of hepatic ISGs was strongly correlated with $Y$-GTP and weakly correlated with insulin resistance. A recent study describing the association between insulin resistance and poor treatment outcome might be partially explained by this observation. ${ }^{20}$

In this study, we utilized 3 ISGs (Mx1, IFI44, and IFIT1) out of 15 validated by RTD-PCR. The expression values of these ISGs were higher than those of other ISGs (Supplemental Fig. 1A). We averaged these ISGs and set the cut-off value as 3.5 from the ROC curve (Supplemental Fig. 1B). The sensitivity, specificity, and positive and negative predictive values on the likelihood of achieving SVR+TR using this cut-off value were $82 \%$ (103/125), 72\% (31/43), 90\% (103/115), and 58\% (31/53), respectively. The results were compared with those observed for the 15 ISGs (Supplemental Table 5). These results showed that the 3.5 cut-off value for Mx1, IFI44, and IFIT1 would be valuable for clinical use.

Despite the importance of the expression of hepatic ISGs, viral factors may also allow us to predict the outcome of treatment. Multivariate analysis showed that ISDR mutations $(\geqq 2)$ independently contributed to the treatment outcome, although univariate analysis did not show significance $(p=0.07)$; therefore, ISDR might be uniquely and differentially involved in treatment resistance.

What causes the differences in the expression of hepatic ISGs? In parallel to the 
gene expression analysis, a GWAS was applied to identify genomic loci associated with treatment response, and a polymorphism in IL28B was found to predict hepatitis C treatment-induced viral clearance..$^{10-12}$ To examine the relationship between the genetic variation of IL28B and hepatic gene expression, we determined the IL28B polymorphism in 91 patents (Table 3). The patients with the minor genotype (TG or GG) had an increased expression of hepatic ISGs compared with the patients with major genotype (TT) (Figs. 2, 3). In European-Americans, the proportion of major homozygotes is 39\% (CC at rs1297986), $49 \%$ for heterozygotes (TC), and $12 \%$ for minor homozygotes (TT). ${ }^{11}$ Although the proportion of minor homozygotes was much less in this study ( $\mathrm{GG}=4 \%$ ), as reported in a previous study in Japan, ${ }^{12}$ more patients are required for proper evaluation. It is interesting that the expression of hepatic ISGs in minor homozygotes (GG) was higher than in heterozygotes (TG) in this study.

The results clearly showed that the differences in the expression of hepatic ISGs before treatment are associated with the IL28B polymorphism and results in different treatment outcomes. Although we could not detect significant differences in the expression levels of IL28B depending on the different SNP, some patients with the major genotype showed a higher expression of IL28B. As IL28B expression was approximately tenfold less than the expression of ISGs, the lower expression of IL28B may be a reason for the decreased ability to distinguish differences in its expression. Another possibility may be the specificity of the IL28B primers used in this study; as IL28B shares a $98.2 \%$ nucleotide sequence homology with IL28A, IL28B specific primers are not available. ${ }^{21}$ When the expression of IL28B and hepatic ISGs were compared, a significant correlation was observed and, interestingly, IL28B and ISGs derived from different SNPs were correlated in a different way (Figs. 3C, D). It appeared that hepatic ISGs were more induced by the reduced amounts of IL28B in patients with the minor genotype. The mechanism behind these findings has yet to be determined; however, IL28B interacts with a heterodimeric class II cytokine receptor that 
consists of IL-10 receptor $\beta$ (IL-10R $\beta$ ) and IL-28 receptor $\alpha$ (IL-28R $\alpha) \cdot{ }^{18,19}$ It is possible that IL28B could mediate anti-viral signaling through IL-10 signaling as well as STAT1 activation. The Th2 dominant signaling of IL28B may modulate signaling pathways in livers with $\mathrm{CH}-\mathrm{C}$ and contributes to the different expression of ISGs. Another possibility may be that the cell origin of hepatic ISGs is different. A recent study revealed cell-type specific ISG expression in macrophages and hepatocytes, which could be related to the IFN response. ${ }^{22}$ As more of the B-cell-, dendritic cell-, and NK cell-related genes were up-regulated in the liver of patients with the major genotype, ISGs could be expressed by these cells, while they are expressed by hepatocytes in the liver of patients with the minor genotype. It is known that the induction of ISGs in lymphocytes is lower than that in hepatocytes. The precise mechanism should be investigated further as a different regulatory mechanism for the expression of ISGs may be present.

In conclusion, we presented the clinical relevance of the expression of hepatic ISGs for the treatment outcome of Peg-IFN and RBV combination therapy. The different expressions of hepatic ISGs before treatment might be due to polymorphisms in IL28B. Further studies are required to clarify the detailed pathways of IL28B and hepatic gene expression through molecular biological and immunological aspects.

\section{Acknowledgements}

The authors thank Mina Nishiyama and Yuki Hatayama for excellent technical assistance. 


\section{Appendix A}

The Hokuriku Liver Study Group (HLSG) is composed of the following members:

Drs. Takashi Kagaya, Kuniaki Arai, Kaheita Kakinoki, Kazunori Kawaguchi, Hajime Takatori, Hajime Sunakosaka (Department of Gastroenterology, Kanazawa University Graduate School of Medicine, Kanazawa); Drs. Touru Nakahama, Shinji Kamiyamamoto, (Kurobe City Hospital, Kurobe, Toyama); Dr. Yasuhiro Takemori (Toyama Rosai Hospital, Uozu, Toyama); Dr. Hikaru Oguri (Koseiren Namerikawa Hospital, Namerikawa, Toyama); Drs. Yatsugi Noda, Hidero Ogino (Toyama Prefectural Central Hospital, Toyama, Toyama); Drs. Yoshinobu Hinoue, Keiji Minouchi (Toyama City Hospital, Toyama, Toyama); Dr. Nobuyuki Hirai (Koseiren Takaoka Hospital, Takaoka, Toyama); Drs. Tatsuho Sugimoto, Koji Adachi (Tonami General Hospital, Tonam, Toyama); Dr. Yuichi Nakamura (Noto General Hospital, Nanao, Ishikawa); Drs. Masashi Unoura, Ryuhei Nishino (Public Hakui Hospital, Hakui, Ishikawa); Drs. Hideo Morimoto, Hajime Ohta (National Hospital Organization Kanazawa Medical Center, Kanazawa, Ishikawa); Dr. Hirokazu Tsuji (Kanazawa Municipal Hospital, Kanazawa, Ishikawa); Drs. Akira Iwata, Shuichi Terasaki (Kanazawa Red Cross Hospital, Kanazawa, Ishikawa); Drs. Tokio Wakabayashi, Yukihiro Shirota (Saiseikai Kanazawa Hospital, Kanazawa, Ishikawa); Drs. Takeshi Urabe, Hiroshi Kawai (Public Central Hospital of Matto Ishikawa, Hakusan, Ishikawa); Dr. Yasutsugu Mizuno (Nomi Municipal Hospital, Nom, Ishikawa); Dr. Shoni Kameda (Komatsu Municipal Hospital, Komatsu); Drs. Hirotoshi Miyamori, Uichiro Fuchizaki (Keiju Medical Center, Nanao, Ishikawa); Dr. Haruhiko Shyugo (Kanazawa Arimatsu Hospital, Kanazawa, Ishikawa); Dr. Hideki Osaka (Yawata Medical Center, Komatsu, Ishikawa); Dr. Eiki Matsushita (Kahoku Central Hospital, Tsubata, Ishikawa); Dr. Yasuhiro Katou (Katou Hospital, Komatsu, Ishikawa); Drs. Nobuyoshi Tanaka, Kazuo Notumata (Fukuiken Saiseikai Hospital, Fukuil, Fukui); Dr. Mikio Kumagai (Kumagai Clinic, Tsurugal, Fukui); Dr. Manabu Yoneshima (Municipal Tsuruga Hospital, Tsurugal, Fukui)

\section{References}

1. Kiyosawa K, Sodeyama T, Tanaka E, et al. Interrelationship of blood transfusion, non-A, non-B hepatitis and hepatocellular carcinoma: analysis by detection of antibody to hepatitis C virus. Hepatology 1990;12:671-675.

2. Fried MW, Shiffman ML, Reddy KR, et al. Peginterferon alfa-2a plus ribavirin for chronic hepatitis C virus infection. N Engl J Med 2002;347:975-982. 
3. Poynard T, Ratziu V, McHutchison J, et al. Effect of treatment with peginterferon or interferon alfa-2b and ribavirin on steatosis in patients infected with hepatitis $\mathrm{C}$. Hepatology 2003;38:75-85.

4. Enomoto N, Sakuma I, Asahina Y, et al. Mutations in the nonstructural protein 5A gene and response to interferon in patients with chronic hepatitis $\mathrm{C}$ virus $1 \mathrm{~b}$ infection. $\mathrm{N}$ Engl J Med 1996;334:77-81.

5. Okanoue $\mathrm{T}$, Itoh $\mathrm{Y}, \mathrm{Hashimoto} \mathrm{H}$, et al. Predictive values of amino acid sequences of the core and NS5A regions in antiviral therapy for hepatitis C: a Japanese multi-center study. J Gastroenterol 2009;44:952-963.

6. Feld JJ, Nanda S, Huang Y, et al. Hepatic gene expression during treatment with peginterferon and ribavirin: Identifying molecular pathways for treatment response. Hepatology 2007;46:1548-1563.

7. Sarasin-Filipowicz M, Oakeley EJ, Duong FH, et al. Interferon signaling and treatment outcome in chronic hepatitis C. Proc Natl Acad Sci U S A 2008;105:7034-7039.

8. Asselah T, Bieche I, Narguet S, et al. Liver gene expression signature to predict response to pegylated interferon plus ribavirin combination therapy in patients with chronic hepatitis C. Gut 2008;57:516-524.

9. Chen L, Borozan I, Feld J, et al. Hepatic gene expression discriminates responders and nonresponders in treatment of chronic hepatitis C viral infection. Gastroenterology 2005;128:1437-1444.

10. Thomas DL, Thio CL, Martin MP, et al. Genetic variation in IL28B and spontaneous clearance of hepatitis C virus. Nature 2009;461:798-801.

11. Ge D, Fellay J, Thompson AJ, et al. Genetic variation in IL28B predicts hepatitis C treatment-induced viral clearance. Nature 2009;461:399-401.

12. Tanaka Y, Nishida N, Sugiyama M, et al. Genome-wide association of IL28B with response to pegylated interferon-alpha and ribavirin therapy for chronic hepatitis $\mathrm{C}$. 
Nat Genet 2009;41:1105-1109.

13. Desmet VJ, Gerber M, Hoofnagle JH, et al. Classification of chronic hepatitis:

diagnosis, grading and staging. Hepatology 1994;19:1513-1520.

14. Honda M, Yamashita T, Ueda T, et al. Different signaling pathways in the livers of patients with chronic hepatitis B or chronic hepatitis C. Hepatology 2006;44:1122-1138.

15. Honda M, Kaneko S, Kawai $\mathrm{H}$, et al. Differential gene expression between chronic hepatitis B and C hepatic lesion. Gastroenterology 2001;120:955-966.

16. Shipley B. A new inferential test for path models based on directed acyclic graphs. Structural Equation Modeling 2000;7:206-218.

17. Favre M, Martin J, Festa-Bianchet M. Determinants and life-history consequences of social dominance in bighorn ewes. Animal Behaviour 2008;76:1373-1380.

18. Sheppard P, Kindsvogel W, Xu W, et al. IL-28, IL-29 and their class II cytokine receptor IL-28R. Nat Immunol 2003;4:63-68.

19. Kotenko SV, Gallagher G, Baurin VV, et al. IFN-lambdas mediate antiviral protection through a distinct class II cytokine receptor complex. Nat Immunol 2003;4:69-77.

20. Camma C, Bruno S, Di Marco V, et al. Insulin resistance is associated with steatosis in nondiabetic patients with genotype 1 chronic hepatitis C. Hepatology 2006;43:64-71.

21. Mihm S, Frese M, Meier V, et al. Interferon type I gene expression in chronic hepatitis C. Lab Invest 2004;84:1148-1159.

22. Chen L, Borozan I, Sun J, et al. Cell-type specific gene expression signature in liver underlies response to interferon therapy in chronic hepatitis $\mathrm{C}$ infection. Gastroenterology 2009; doi:10.1053/j.gastro.2009.10.046. 


\section{Figure Legends}

\section{Figure 1}

Hierarchical clustering analysis of 91 patients using 37 representative ISGs. Responses to therapy (SVR, TR, and NR), fibrosis stage (F1-4), and status; ISDR mutations are also shown. ISDR mutation $\geqq 2=\mathrm{M}, \leqq 1=0$.

\section{Figure 2}

Hierarchical clustering analysis of 91 patients with the defined genotype of IL28B.

Responses to therapy (SVR, TR, and NR) and IL28B genotype (TT, TG, or GG) are shown. The structure of the dendrogram and heatmap is the same as in Figure 1.

\section{Figure 3}

A: IL28 expression in the liver of 91 patients with the major (TT) or minor (TG or GG) genotype (rs8099917).

B: Expression of ISGs in the liver of patients with the major (TT) or minor (TG or GG) genotype (rs8099917).

C: Relationship between IL28 and ISGs in the liver of patients with the major (TT) genotype (rs8099917).

D: Relationship between IL28 and ISGs in the liver of patients with the minor (TG or GG) genotype (rs8099917).

\section{Supplemental Figure 1}

A: Box plots of ISG expression in 168 patients detected by RTD-PCR.

B: Receiver operating characteristic (ROC) curve and area under the curve (AUC) of ISGs on the likelihood of achieving SVR+TR. 


\section{Supplemental Figure 2}

Relationship of the expression of hepatic ISGs and HCV-RNA with different treatment responses (SVR or TR vs. NR).

\section{Supplemental Figure 3}

Pathway analysis of differentially expressed genes in the liver of patients with the major (TT) or minor (TG or GG) genotype (rs8099917) using MetaCore. The frequently observed pathway processes are listed in their order of significance. 
Table 1

Comparison of clinical factors between patients with and without NR

\begin{tabular}{|c|c|c|c|c|c|c|c|}
\hline Clinical category & SVR+TR & & NR & & $\begin{array}{c}\text { Univariate } \\
\mathrm{p} \text {-value }\end{array}$ & $\begin{array}{c}\text { Multivariate } \\
\text { Odds }(95 \% \mathrm{Cl})\end{array}$ & $\begin{array}{c}\text { Multivariate } \\
\mathrm{p} \text {-value }\end{array}$ \\
\hline No. of patients & $n=125$ & & $n=43$ & & & - & \\
\hline \multicolumn{8}{|l|}{ Age and gender } \\
\hline Age $(y)$ & 57 & $(30-72)$ & 56 & $(30-73)$ & 0.927 & - & \\
\hline Sex (M vs. F) & 68 vs. 57 & & 24 vs. 19 & & 0.872 & - & \\
\hline \multicolumn{8}{|l|}{ Liver factors } \\
\hline $\begin{array}{l}\text { F stage (F1-2 vs. F3-4) } \\
\text { A grade (A0-1 vs. A2-3) } \\
\text { ISGs (Mx, IFI44, IFIT1) }\end{array}$ & $\begin{array}{l}95 \text { vs. } 30 \\
68 \text { vs. } 57\end{array}$ & & $\begin{array}{l}20 \text { vs. } 23 \\
19 \text { vs. } 24\end{array}$ & & $\begin{array}{l}0.001 \\
0.248\end{array}$ & $\begin{array}{c}4.18(1.61-11.5) \\
-\end{array}$ & 0.003 \\
\hline$(<3.5$ vs. $\geqq 3.5)$ & 103 vs. 22 & & 12 vs. 31 & & $<0.001$ & $16.2(6.21-47.8)$ & $<0.001$ \\
\hline \multicolumn{8}{|l|}{ Laboratory parameters } \\
\hline HCV-RNA (KIU/ml) & 2300 & $(126-5000)$ & 1930 & $(140-5000)$ & 0.725 & - & \\
\hline $\mathrm{BMI}\left(\mathrm{kg} / \mathrm{m}^{2}\right)$ & 23.2 & $(16.3-34.7)$ & 23.4 & $(19.5-40.6)$ & 0.439 & - & 0.107 \\
\hline AST (IU/L) & 46 & $(18-258)$ & 64 & $(21-283)$ & 0.017 & - & \\
\hline ALT (IU/L) & 60 & $(16-376)$ & 82 & $(18-345)$ & 0.052 & - & \\
\hline V-GTP (IU/L) & 36 & $(4-367)$ & 75 & $(26-392)$ & $<0.001$ & - & \\
\hline WBC $\left(/ \mathrm{mm}^{3}\right)$ & 4800 & $(2100-11100)$ & 4800 & $(2500-8200)$ & 0.551 & - & \\
\hline $\mathrm{Hb}(\mathrm{g} / \mathrm{dl})$ & 14 & $(9.3-16.6)$ & 14.4 & $(11.2-17.2)$ & 0.099 & - & \\
\hline $\operatorname{PLT}\left(\times 10^{4} / \mathrm{mm}^{3}\right)$ & 15.7 & $(7-39.4)$ & 15.2 & $(7.6-27.8)$ & 0.378 & - & \\
\hline $\mathrm{TG}(\mathrm{mg} / \mathrm{dl})$ & 98 & $(30-323)$ & 116 & $(45-276)$ & 0.058 & - & \\
\hline T-Chol (mg/dl) & 167 & $(90-237)$ & 160 & $(81-214)$ & 0.680 & - & \\
\hline LDL-Chol (mg/dl) & 82 & $(36-134)$ & 73 & $(29-123)$ & 0.019 & - & \\
\hline HDL-Chol (mg/dl) & 42 & $(20-71)$ & 47 & $(18-82)$ & 0.098 & - & \\
\hline FBS (mg/dl) & 94 & $(60-291)$ & 96 & $(67-196)$ & 0.139 & - & \\
\hline Insulin $(\mu \mathrm{U} / \mathrm{ml})$ & 6.6 & $(0.7-23.7)$ & 6.8 & $(2-23.7)$ & 0.039 & - & \\
\hline HOMA-IR & 1.2 & $(0.3-11.7)$ & 1.2 & $(0.4-7.2)$ & 0.697 & - & \\
\hline \multicolumn{8}{|l|}{ Viral factors } \\
\hline ISDR mutations $\leqq 1$ vs. $\geqq 2$ & 80 vs. 44 & & 34 vs. 9 & & 0.070 & $5.09(1.69-17.8)$ & 0.003 \\
\hline \multicolumn{8}{|l|}{ Treatment factors } \\
\hline \multicolumn{8}{|l|}{ Total dose administered } \\
\hline Peg-IFN $(\mu \mathrm{g})$ & 3840 & $(960-7200)$ & 3840 & $(1920-2880)$ & 0.916 & - & \\
\hline RBV $(\mathrm{g})$ & 202 & $(134-336)$ & 202 & $(36-336)$ & 0.531 & - & \\
\hline \multicolumn{8}{|l|}{$\begin{array}{c}\text { Achieved administration rate } \\
\text { Peg-IFN (\%) }\end{array}$} \\
\hline$\geqq 80 \%$ & 84 & & 28 & & 0.975 & - & \\
\hline$<80 \%$ & 42 & & 14 & & & & \\
\hline RBV (\%) & & & & & & & \\
\hline$\geqq 80 \%$ & 76 & & 24 & & 0.745 & - & \\
\hline$<80 \%$ & 50 & & 18 & & & & \\
\hline Achievement of EVR & $101 / 125(81 \%)$ & & $0 / 43(0 \%)$ & & $<0.001$ & - & \\
\hline
\end{tabular}

BMI, body mass index; AST, aspartate aminotransferase

ALT, alanine aminotransferase; $\gamma$-GTP, gamma-glutamyl transpeptidase WBC, leukocytes; Hb, hemoglobin; PLT, platelets; TG, triglycerides

T-chol, total cholesterol; LDL-chol, low density lipoprotein cholesterol HDL-chol, high density lipoprotein cholesterol; FBS, fasting blood sugar $\mathrm{Cl}$, confidence interval 
Table 2

Clinical factors associated with expression of hepatic ISGs

\begin{tabular}{|c|c|c|c|c|c|c|c|c|}
\hline \multirow[t]{2}{*}{ Clinical factor } & \multicolumn{4}{|c|}{ Univariate } & \multicolumn{4}{|c|}{ Multivariate } \\
\hline & $\beta$ & 95 & $6 \mathrm{Cl}$ & $p$ value & $\beta$ & $95^{\circ}$ & $6 \mathrm{Cl}$ & $p$ value \\
\hline AST (IU/L) & 0.274 & 0.13 & 0.42 & $<0.001$ & - & - & - & \\
\hline V-GTP (IU/L) & 0.326 & 0.18 & 0.47 & $<0.001$ & 0.288 & 0.14 & 0.43 & $<0.001$ \\
\hline HCV-RNA (KIU/ml) & -0.170 & -3.19 & -0.02 & 0.025 & -0.255 & -0.40 & -0.11 & $<0.001$ \\
\hline SVR+TR & -0.237 & -0.32 & -0.05 & 0.009 & - & - & - & \\
\hline NR & -0.168 & -0.57 & 0.18 & 0.298 & - & - & - & \\
\hline FBS (mg/dl) & 0.182 & 0.03 & 0.35 & 0.021 & - & - & - & \\
\hline Insulin $(\mu \mathrm{U} / \mathrm{ml})$ & 0.190 & 0.03 & 0.34 & 0.016 & - & - & - & \\
\hline HOMA-IR & 0.181 & 0.03 & 0.33 & 0.017 & - & - & - & 0.073 \\
\hline TG (mg/dl) & 0.201 & 0.05 & 0.35 & 0.011 & - & - & - & 0.089 \\
\hline LDL-Chol (mg/dl) & -0.177 & -0.33 & -0.02 & 0.025 & -0.143 & -0.28 & 0.00 & 0.048 \\
\hline
\end{tabular}

Y-GTP, gamma-glutamyl transpeptidase; AST, aspartate aminotransferase

FBS, fasting blood sugar; TG, triglycerides

LDL-chol, low density lipoprotein cholesterol

$\mathrm{Cl}$, confidence interval

$\beta$, $\beta$ coefficient

$\mathrm{Cl}$, confidence interval 
Table 3 Clinical characteristics of 32 patients genotyped by GW AS and 5 SNPs in strong linkage disequilibrium with IL28B, including rs $12979860{ }^{11)}$

\begin{tabular}{|c|c|c|c|c|c|c|c|c|c|c|c|c|}
\hline \multirow[t]{2}{*}{ Pt. No. } & \multirow[t]{2}{*}{ Response } & \multirow[t]{2}{*}{ Age (y) } & \multirow[t]{2}{*}{ Sex } & \multirow[t]{2}{*}{ F stage } & \multirow[t]{2}{*}{ ISGs } & \multirow[t]{2}{*}{ IL28B } & \multirow{2}{*}{$\begin{array}{c}\begin{array}{c}\text { RefSNP } \\
\text { (chr pos) }\end{array} \\
\text { Minor } \\
\text { allele }\end{array}$} & $\begin{array}{r}\text { rs8105790 } \\
(44424341) \\
\end{array}$ & \multirow{2}{*}{$\begin{array}{c}\begin{array}{r}\text { rs11881222 } \\
(44426763)\end{array} \\
G\end{array}$} & \multirow{2}{*}{$\begin{array}{c}\begin{array}{c}\text { rs12979860 } \\
(44430627)\end{array} \\
T\end{array}$} & \multirow{2}{*}{$\begin{array}{c}\text { rs8099917 } \\
(44435005) \\
G\end{array}$} & \multirow{2}{*}{$\begin{array}{c}\text { rs7248668 } \\
(44435661) \\
\text { A }\end{array}$} \\
\hline & & & & & & & & C & & & & \\
\hline 1 & $\overline{\text { SVR }}$ & 42 & $\bar{M}$ & 1 & 4.20 & 83.8 & & $\overline{\mathrm{TT}}$ & $\overline{A A}$ & $\mathrm{CC}$ & $\overline{\mathrm{TT}}$ & $\overline{\mathrm{GG}}$ \\
\hline 2 & SVR & 59 & $M$ & 1 & 2.62 & 45.5 & & $\mathrm{TT}$ & $A A$ & $\mathrm{CC}$ & $\mathrm{TT}$ & $\mathrm{GG}$ \\
\hline 3 & SVR & 41 & $\mathrm{~F}$ & 1 & 1.54 & 1.3 & & $\mathrm{TT}$ & $A A$ & $\mathrm{CC}$ & $\mathrm{TT}$ & $\mathrm{GG}$ \\
\hline 4 & TR & 57 & M & 1 & 3.18 & 21.7 & & $\mathrm{TT}$ & $A A$ & $\mathrm{CC}$ & $\mathrm{TT}$ & $\mathrm{GG}$ \\
\hline 5 & TR & 68 & $\mathrm{~F}$ & 1 & 1.43 & 20.3 & & $\mathrm{TT}$ & $A A$ & $\mathrm{CC}$ & $\mathrm{TT}$ & $\mathrm{GG}$ \\
\hline 6 & SVR & 44 & $M$ & 1 & 0.97 & 4.6 & & $\mathrm{TT}$ & $A A$ & $\mathrm{CC}$ & $\mathrm{TT}$ & GG \\
\hline 7 & SVR & 61 & M & 2 & 2.15 & 6.1 & & $\mathrm{TT}$ & $A A$ & CC & $\mathrm{TT}$ & GG \\
\hline 8 & SVR & 50 & M & 2 & 3.25 & 66.4 & & TT & AA & CC & TT & GG \\
\hline 9 & SVR & 49 & M & 2 & 1.25 & ND & & $\mathrm{TT}$ & $A A$ & $\mathrm{CC}$ & $\mathrm{TT}$ & $\mathrm{GG}$ \\
\hline 10 & TR & 59 & $\mathrm{~F}$ & 2 & 1.29 & 17.4 & & TT & AA & CC & TT & GG \\
\hline 11 & SVR & 48 & $\mathrm{~F}$ & 2 & 1.00 & 90.2 & & TT & AA & CC & TT & GG \\
\hline 12 & TR & 65 & $\mathrm{~F}$ & 2 & 2.86 & 36.4 & & $\mathrm{TT}$ & $A A$ & $\mathrm{CC}$ & $\mathrm{TT}$ & $\mathrm{GG}$ \\
\hline 13 & NR & 34 & M & 3 & 0.82 & 17.8 & & TT & AA & CC & TT & GG \\
\hline 14 & SVR & 55 & M & 3 & 0.83 & 13.8 & & $\mathrm{TT}$ & $A A$ & $\mathrm{CC}$ & $\mathrm{TT}$ & $\mathrm{GG}$ \\
\hline 15 & TR & 68 & M & 3 & 0.75 & 20.6 & & TT & AA & CC & TT & GG \\
\hline 16 & SVR & 64 & M & 3 & 0.94 & 15.7 & & TT & AA & CC & TT & GG \\
\hline 17 & SVR & 67 & $\mathrm{~F}$ & 3 & 1.50 & 25.7 & & TT & AA & CC & TT & GG \\
\hline 18 & SVR & 48 & M & 4 & 1.69 & 7.9 & & TT & AA & $\mathrm{CC}$ & TT & GG \\
\hline 19 & NR & 66 & $\mathrm{~F}$ & 1 & 4.57 & 16.5 & & TC & $A G$ & CT & TG & $\mathrm{GA}$ \\
\hline 20 & SVR & 52 & $\mathrm{~F}$ & 1 & 5.23 & 29.3 & & TC & $A G$ & CT & TG & GA \\
\hline 21 & NR & 55 & $\mathrm{~F}$ & 1 & 8.25 & 57.2 & & TC & $A G$ & CT & TG & GA \\
\hline 22 & SVR & 49 & $\mathrm{~F}$ & 1 & 5.36 & ND & & TC & $A G$ & CT & TG & $\mathrm{GA}$ \\
\hline 23 & TR & 44 & M & 1 & 2.08 & 7.0 & & TC & $A G$ & CT & TG & GA \\
\hline 24 & NR & 63 & $M$ & 1 & 2.77 & 10.5 & & TC & $A G$ & CT & TG & GA \\
\hline 25 & NR & 61 & $\mathrm{~F}$ & 2 & 3.98 & 39.1 & & TC & $A G$ & CT & TG & GA \\
\hline 26 & NR & 42 & M & 2 & 4.89 & 5.9 & & TC & $A G$ & CT & TG & GA \\
\hline 27 & SVR & 49 & M & 3 & 3.31 & 6.9 & & TC & $A G$ & CT & TG & GA \\
\hline 28 & TR & 71 & $\mathrm{~F}$ & 3 & 5.53 & 27.3 & & TC & $A G$ & CT & TG & GA \\
\hline 29 & TR & 63 & M & 3 & 3.40 & 33.5 & & TC & $A G$ & CT & TG & GA \\
\hline 30 & NR & 70 & $\mathrm{~F}$ & 3 & 4.78 & 8.1 & & TC & $A G$ & CT & TG & GA \\
\hline 31 & TR & 62 & $\mathrm{~F}$ & 3 & 3.53 & 14.0 & & TC & $A G$ & CT & TG & GA \\
\hline 32 & NR & 56 & M & 4 & 7.37 & 30.8 & & $\mathrm{CC}$ & GG & TT & GG & $\mathrm{AA}$ \\
\hline
\end{tabular}

The Pearson correlation of the $r^{2}$ estimates for adjacent pairs; rs8099917 vs. rs8105790, rs8099917 vs. rs 11881222 , rs 8099917 vs. rs 12979860 , and rs8099917 vs. rs $7248668=0.99,0.99,0.98$, and 0.97 , respectively. 
Table 4

Comparison of clinical factors between patients with major (TT) and minor $(T G+G G)$ alleles

\begin{tabular}{|c|c|c|c|c|c|c|c|}
\hline Clinical category & TT & & TG+GG & & $\begin{array}{c}\text { Univariate } \\
\text { p-value }\end{array}$ & $\begin{array}{c}\text { Multivariate } \\
\text { Odds }(95 \% \mathrm{Cl})\end{array}$ & $\begin{array}{c}\begin{array}{c}\text { Multivariate } \\
\text { p-value }\end{array} \\
\end{array}$ \\
\hline No. of patients & $\mathrm{n}=60$ & & $\mathrm{n}=31$ & & & - & \\
\hline \multicolumn{8}{|l|}{ Treatment response } \\
\hline SVR+TR vs NR & 51 vs. 9 & & 11 vs. 20 & & $<0.001$ & - & \\
\hline \multicolumn{8}{|l|}{ Age and gender } \\
\hline Age $(y)$ & 56 & $(30-69)$ & 56 & $(30-71)$ & 0.843 & - & \\
\hline Sex (M vs. F) & 39 vs. 21 & & 19 vs. 12 & & 0.518 & - & \\
\hline \multicolumn{8}{|l|}{ Liver factors } \\
\hline F stage (F1-2 vs. F3-4) & 36 vs. 24 & & 23 vs. 17 & & 0.905 & - & \\
\hline A grade (A0-1 vs. $\mathrm{A} 2-3$ ) & 27 vs. 33 & & 20 vs. 11 & & 0.075 & - & \\
\hline \multicolumn{8}{|l|}{ ISGs (Mx, IFI44, IFIT1) } \\
\hline$(<3.5$ vs. $\geqq 3.5)$ & 46 vs. 14 & & 5 vs. 26 & & $<0.001$ & $18.1(3.95-113)$ & $<0.001$ \\
\hline \multicolumn{8}{|l|}{ Laboratory parameters } \\
\hline HCV-RNA (KIU/ml) & 2055 & $(160-5000)$ & 1970 & $(126-5000)$ & 0.602 & - & \\
\hline BMl $\left(\mathrm{kg} / \mathrm{m}^{2}\right)$ & 24.5 & $(16.3-40.5)$ & 22.9 & $(19.1-26.6)$ & 0.006 & - & 0.077 \\
\hline AST (IU/L) & 59 & $(22-258)$ & 54 & $(21-283)$ & 0.227 & - & \\
\hline ALT (IU/L) & 75 & $(24-376)$ & 60 & $(18-236)$ & 0.077 & - & \\
\hline y-GTP (IU/L) & 61 & $(4-392)$ & 53 & $(20-229)$ & 0.517 & - & 0.167 \\
\hline WBC $\left(/ \mathrm{mm}^{3}\right)$ & 4450 & $(2100-11100)$ & 4600 & $(2500-8200)$ & 0.947 & - & \\
\hline $\mathrm{Hb}(\mathrm{g} / \mathrm{dl})$ & 14.2 & $(11.4-16.7)$ & 14.5 & $(11.2-17.2)$ & 0.606 & - & \\
\hline $\operatorname{PLT}\left(\times 10^{4} / \mathrm{mm}^{3}\right)$ & 15.4 & $(7-39.4)$ & 16.2 & $(9.2-27.7)$ & 0.832 & - & \\
\hline $\mathrm{TG}(\mathrm{mg} / \mathrm{dl})$ & 98 & $(58-248)$ & 131 & $(30-303)$ & 0.053 & - & 0.055 \\
\hline $\mathrm{T}$-Chol (mg/dl) & 172 & $(115-222)$ & 168 & $(129-237)$ & 0.910 & - & \\
\hline LDL-Chol (mg/dl) & 84 & $(42-123)$ & 69 & $(51-107)$ & 0.052 & - & 0.055 \\
\hline HDL-Chol (mg/dl) & 44 & $(18-72)$ & 45 & $(29-77)$ & 0.218 & - & \\
\hline FBS $(\mathrm{mg} / \mathrm{dl})$ & 95 & $(59-291)$ & 96 & $(66-206)$ & 0.849 & - & \\
\hline Insulin $(\mu \mathrm{U} / \mathrm{ml})$ & 7.5 & $(0.7-23.2)$ & 9.2 & $(2-23.2)$ & 0.195 & - & \\
\hline HOMA-IR & 1.3 & $(0.3-11.7)$ & 1.2 & $(0.4-9.6)$ & 0.339 & - & \\
\hline \multicolumn{8}{|l|}{ Viral factors } \\
\hline ISDR mutations ( $\leqq 1$ vs. $\geqq 2$ ) & 38 vs. 22 & & 23 vs. 7 & & 0.194 & - & 0.083 \\
\hline \multicolumn{8}{|l|}{ Treatment factors } \\
\hline Peg-IFN $(\mu \mathrm{g})$ & 3960 & $(1500-7200)$ & 3840 & $(1920-5760)$ & 0.377 & - & \\
\hline $\operatorname{RBV}(\mathrm{g})$ & 203 & $(26-336)$ & 201 & $(106-268)$ & 0.777 & - & \\
\hline \multirow{2}{*}{\multicolumn{8}{|c|}{ Achieved administration rate }} \\
\hline & & & & & & & \\
\hline$\geqq 80 \%$ & 41 & & 17 & & 0.207 & - & \\
\hline $\begin{array}{l}<80 \% \\
\text { RBV }(\%)\end{array}$ & 19 & & 14 & & & & \\
\hline$\geqq 80 \%$ & 34 & & 19 & & 0.671 & - & \\
\hline$<80 \%$ & 26 & & 12 & & & & \\
\hline Achievement of EVR & $40 / 60(62 \%)$ & & $9 / 31(29 \%)$ & & $<0.001$ & - & \\
\hline
\end{tabular}

BMI, body mass index; AST, aspartate aminotransferase

ALT, alanine aminotransferase; $\mathrm{Y}$-GTP, gamma-glutamyl transpeptidase

WBC, leukocytes; $\mathrm{Hb}$, hemoglobin; PLT, platelets; TG; triglycerides

T-chol, total cholesterol; LDL-chol, low density lipoprotein cholesterol

HDL-chol, high density lipoprotein cholesterol; FBS; fasting blood sugar

$\mathrm{Cl}$, confidence interval 
Fig. 1

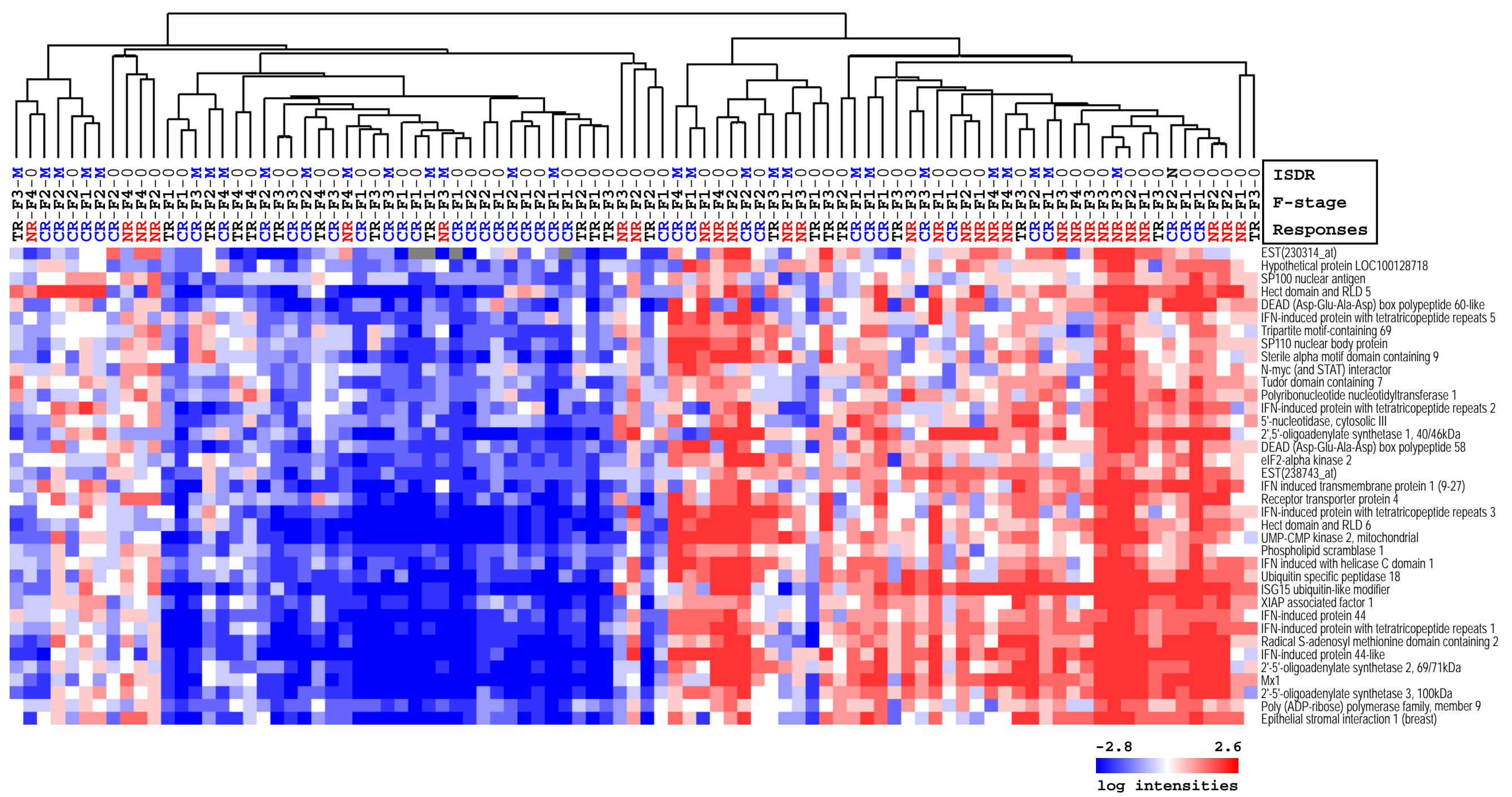


Fig. 2

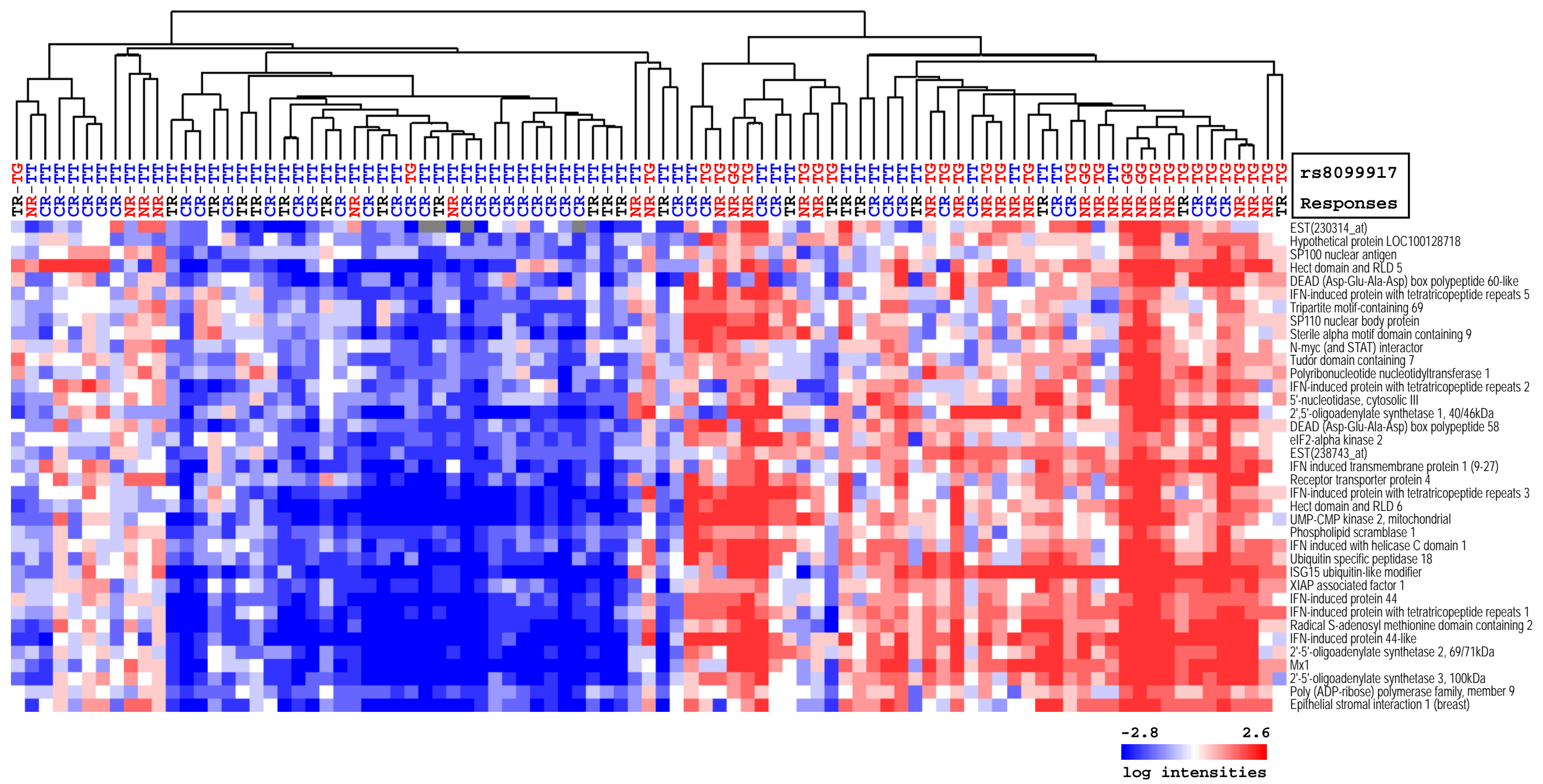


Fig. 3

A

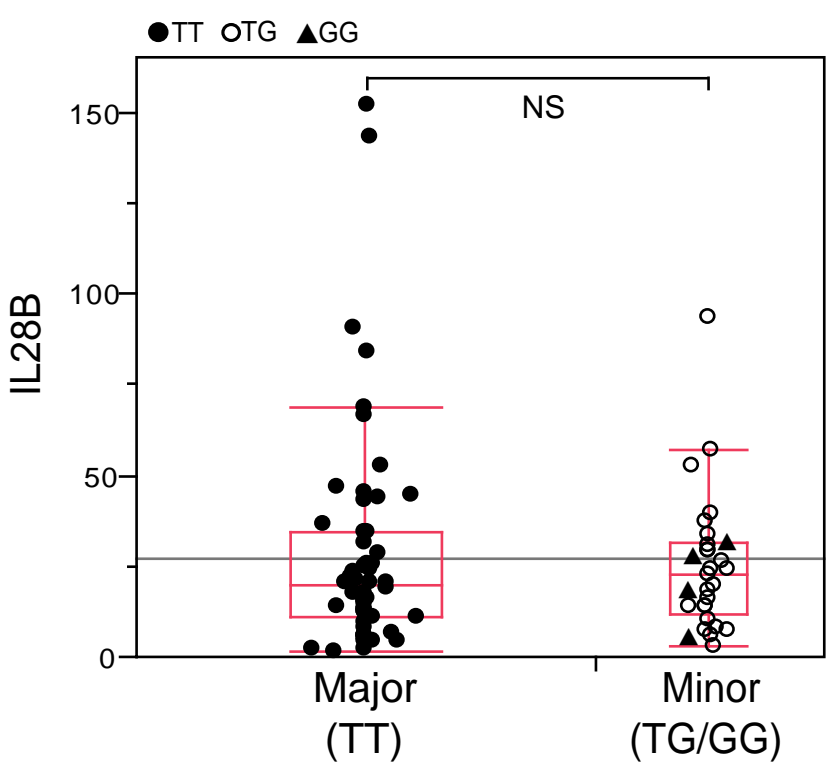

C

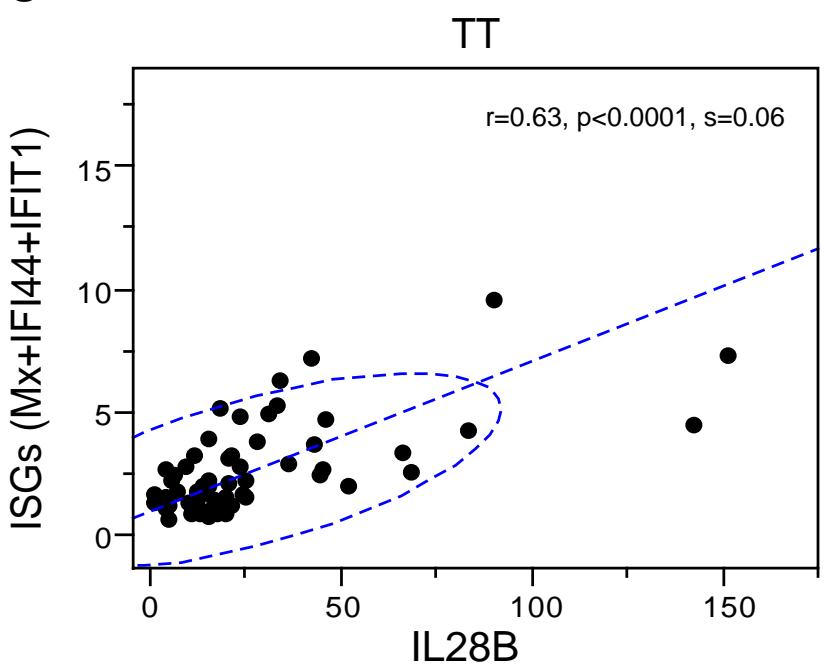

B

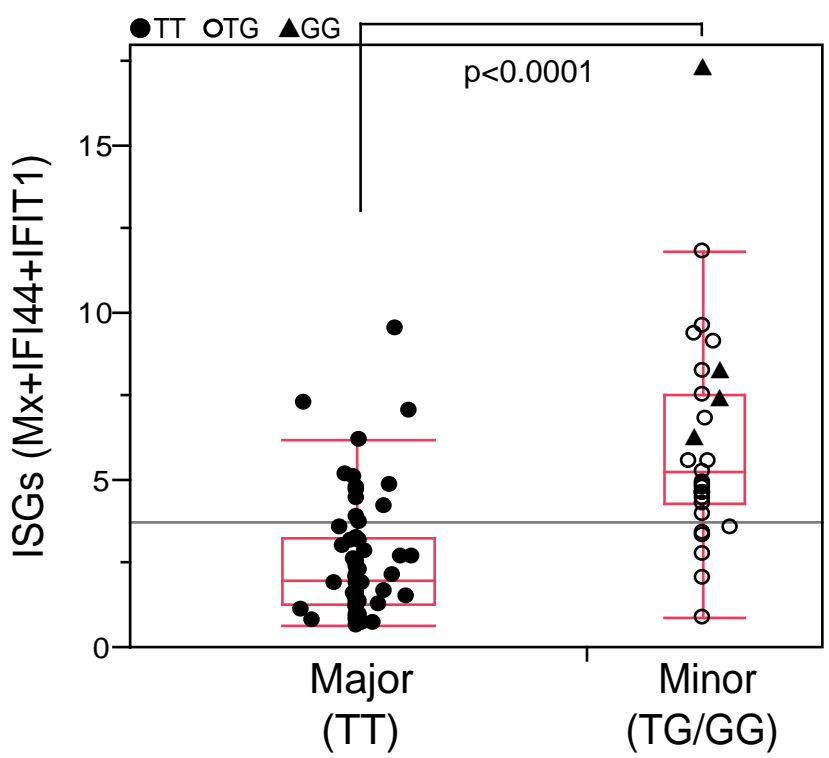

D

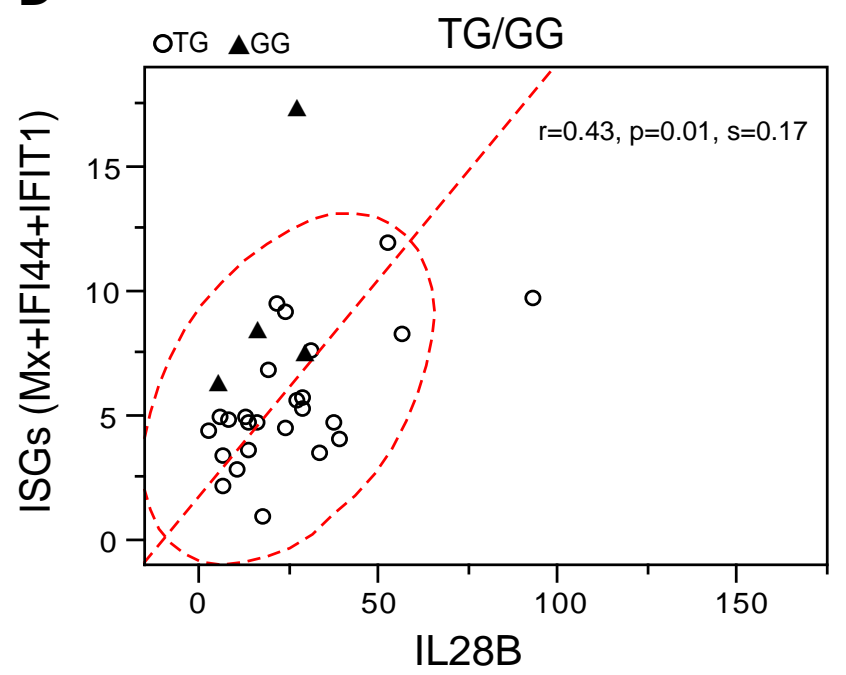


Supplemental Table 1

Clinical characteristics of patients enrolled in this study

\begin{tabular}{|c|c|c|c|c|c|c|}
\hline Clinical category & SVR & & TR & & NR & \\
\hline No. of patients & $n=70$ & & $\mathrm{n}=55$ & & $n=43$ & \\
\hline \multicolumn{7}{|l|}{ Age and gender } \\
\hline Age $(y)$ & 55 & $(30-72)$ & 60 & $(35-72)$ & 57 & $(30-73)$ \\
\hline Sex (M vs. F) & 41 vs. 29 & & 27 vs. 28 & & 24 vs. 19 & \\
\hline \multicolumn{7}{|l|}{ Liver factors } \\
\hline F stage (F1-2 vs. F3-4) & 56 vs. 14 & & 39 vs. 16 & & 20 vs. 23 & \\
\hline A grade (A0-1 vs. $A 2-3)$ & 39 vs. 31 & & 29 vs. 26 & & 19 vs. 24 & \\
\hline ISGs (Mx, IFI44, IFIT1) & 1.89 & $(0.36-9.48)$ & 1.65 & $(0.44-7.69)$ & 4.84 & $(0.82-17.3)$ \\
\hline \multicolumn{7}{|l|}{ Laboratory parameters } \\
\hline HCV-RNA (KIU/ml) & 1800 & $(126-5000)$ & 2600 & $(400-5000)$ & 1930 & $(140-5000)$ \\
\hline BMI $\left(\mathrm{kg} / \mathrm{m}^{2}\right)$ & 23.7 & $(16.3-32.8)$ & 22.8 & $(18.7-34.7)$ & 23.4 & $(19.5-40.6)$ \\
\hline AST (IU/L) & 47 & $(20-258)$ & 46 & $(18-205)$ & 64 & $(21-283)$ \\
\hline $\mathrm{ALT}(\mathrm{IU} / \mathrm{L})$ & 61 & $(17-341)$ & 57 & $(16-376)$ & 82 & $(18-345)$ \\
\hline Y-GTP (IU/L) & 38 & $(4-270)$ & 34 & $(12-367)$ & 75 & (26-392) \\
\hline WBC $\left(/ \mathrm{mm}^{3}\right)$ & 4700 & $(2400-11100)$ & 4900 & $(2100-7600)$ & 4800 & $(2500-8200)$ \\
\hline $\mathrm{Hb}(\mathrm{g} / \mathrm{dl})$ & 14.3 & $(9.3-16.6)$ & 13.5 & $(9.3-16.4)$ & 14.4 & $(11.2-17.2)$ \\
\hline $\operatorname{PLT}\left(\times 10^{4} / \mathrm{mm}^{3}\right)$ & 16.2 & $(7-39.4)$ & 15.2 & $(7.6-27.8)$ & 15.2 & $(7.6-27.8)$ \\
\hline $\mathrm{TG}(\mathrm{mg} / \mathrm{dl})$ & 99 & (30-303) & 92 & $(42-323)$ & 116 & $(45-276)$ \\
\hline T-Chol (mg/dl) & 171 & (116-237) & 163 & (90-229) & 160 & $(81-214)$ \\
\hline LDL-Chol (mg/dl) & 87 & $(42-134)$ & 77 & $(36-122)$ & 73 & $(29-123)$ \\
\hline HDL-Chol (mg/dl) & 43 & $(27-67)$ & 40 & $(20-71)$ & 47 & $(18-82)$ \\
\hline FBS (mg/dl) & 97 & $(60-221)$ & 93 & (65-291) & 96 & $(67-196)$ \\
\hline Insulin $(\mu \mathrm{U} / \mathrm{ml})$ & 7.1 & $(0.7-22)$ & 6.7 & $(2-13.3)$ & 6.8 & $(2-23.7)$ \\
\hline HOMA-IR & 1.3 & $(0.3-11.7)$ & 1.1 & $(0.4-6.2)$ & 1.2 & $(0.4-7.2)$ \\
\hline
\end{tabular}

Viral factors

ISDR mutations $\leqq 1$ vs. $\geqq 2 \quad 35$ vs. 34

45 vs. 10

34 vs. 9

Treatment factors

Total dose administered Peg-IFN $(\mu g)$ RBV (g)

$\begin{array}{ll}3840 & (960-7200) \\ 201 & (13-336)\end{array}$

3840
202

$(1500-5760)$

3840

(1920-2880)

$(36-285)$

202

(36-336)

Achieved administration rate Peg-IFN (\%)

$\begin{array}{cc}\geqq 80 \% & 51 \\ <80 \% & 20 \\ \text { RBV }(\%) & \\ \geqq 80 \% & 47 \\ <80 \% & 24\end{array}$

Achievement of EVR $\quad 65 / 70$ (93\%)

$\begin{array}{cc}33 & 28 \\ 22 & 14 \\ 29 & 24 \\ 26 & 18 \\ 36 / 55(65 \%) & 0 / 43(0 \%)\end{array}$

Data are expressed as median (range)

BMI, body mass index; AST, aspartate aminotransferase

ALT, alanine aminotransferase; $Y$-GTP, gamma-glutamyl transpeptidase

WBC, leukocytes; $\mathrm{Hb}$, hemoglobin; PLT, platelets; TG, triglycerides

T-chol, total cholesterol; LDL-chol, low density lipoprotein cholesterol

HDL-chol, high density lipoprotein cholesterol; FBS, fasting blood sugar 
Supplemental Table 2

Overall plausibility of the treatment response groups is assessed using Fisher's $\mathrm{C}$ statistic

\begin{tabular}{|c|c|c|c|c|c|}
\hline Clinical category & SVR vs. NR & SVR vs. TR & TR vs. NR & SVR vs. TR+NR & SVR+TR vs. NR \\
\hline \multicolumn{6}{|l|}{ Age and gender } \\
\hline Age $(y)$ & 0.498 & 0.004 & 0.300 & 0.014 & 1.000 \\
\hline Sex (M vs. F) & 1.000 & 0.648 & 1.000 & 0.803 & 1.000 \\
\hline \multicolumn{6}{|l|}{ Liver factors } \\
\hline F stage (F1-2 vs. F3-4) & 0.002 & 0.284 & 0.012 & 0.011 & 0.002 \\
\hline A grade (A0-1 vs. $A 2-3)$ & 0.504 & 1.000 & 0.940 & 0.778 & 0.495 \\
\hline ISGs (Mx, IFI44, IFIT1) & 0.002 & 1.000 & 0.002 & 0.004 & 0.001 \\
\hline \multicolumn{6}{|l|}{ Laboratory parameters } \\
\hline HCV-RNA (KIU/ml) & 0.602 & 0.008 & 0.340 & 0.083 & 1.000 \\
\hline BMl $\left(\mathrm{kg} / \mathrm{m}^{2}\right)$ & 0.768 & 0.962 & 0.330 & 1.000 & 0.878 \\
\hline AST (IU/L) & 0.008 & 0.970 & 0.047 & 0.148 & 0.035 \\
\hline ALT (IU/L) & 0.032 & 1.000 & 0.093 & 0.154 & 0.104 \\
\hline Y-GTP (IU/L) & 0.004 & 1.000 & 0.003 & 0.336 & 0.002 \\
\hline WBC $\left(/ \mathrm{mm}^{3}\right)$ & 0.974 & 0.598 & 1.000 & 1.000 & 1.000 \\
\hline $\mathrm{Hb}(\mathrm{g} / \mathrm{dl})$ & 0.606 & 0.236 & 0.033 & 0.774 & 0.198 \\
\hline $\operatorname{PLT}\left(\times 10^{4} / \mathrm{mm}^{3}\right)$ & 0.238 & 0.436 & 1.000 & 0.416 & 0.756 \\
\hline $\mathrm{TG}(\mathrm{mg} / \mathrm{dl})$ & 0.354 & 0.124 & 1.000 & 1.000 & 0.116 \\
\hline T-Chol (mg/dl) & 1.000 & 0.556 & 0.042 & 0.518 & 1.000 \\
\hline LDL-Chol (mg/dl) & 0.018 & 0.626 & 0.232 & 0.072 & 0.039 \\
\hline HDL-Chol (mg/dl) & 0.356 & 0.316 & 0.070 & 1.000 & 0.196 \\
\hline FBS $(\mathrm{mg} / \mathrm{dl})$ & 0.688 & 0.828 & 0.236 & 1.000 & 0.277 \\
\hline Insulin $(\mu \mathrm{U} / \mathrm{ml})$ & 0.014 & 1.000 & 0.018 & 1.000 & 0.078 \\
\hline HOMA-IR & 0.102 & 1.000 & 0.066 & 0.944 & 1.000 \\
\hline \multicolumn{6}{|l|}{ Viral factors } \\
\hline ISDR mutations $\leqq 1$ vs. $\geqq 2$ & 0.004 & 0.002 & 1.000 & 0.002 & 0.139 \\
\hline Statistics (Fisher's C) & 97.748 & 51.196 & 88.204 & 65.599 & 81.059 \\
\hline Probability & 0.000 & 0.156 & 0.000 & 0.011 & 0.000 \\
\hline
\end{tabular}

Fisher's $C$ is defined by $C=-2 \sum \ln \left(p_{i}\right)$ where $p_{i}$ is the probability ( $p$-values) of each independent statement (clinical factors) $\mathrm{C}$ follows a chi-square distribution with $2 \mathrm{k}$ degree of freedom, $\mathrm{k}$ being the number of independent statements. 
Supplemental Table 3

Clinical characteristics of patients analyzed by genechip

\begin{tabular}{|c|c|c|}
\hline Clinical category & Data & Range \\
\hline No. of patients & $\mathrm{n}=91$ & \\
\hline \multicolumn{3}{|l|}{ Age and gender } \\
\hline Age $(y)$ & 56 & $(21-73)$ \\
\hline Sex (M vs. F) & 57 vs. 34 & \\
\hline \multicolumn{3}{|l|}{ Treatment responses } \\
\hline SVR/TR/NR & $41 / 21 / 29$ & \\
\hline \multicolumn{3}{|l|}{ Liver factors } \\
\hline F stage $(1 / 2 / 3 / 4)$ & $32 / 23 / 25 / 11$ & \\
\hline A grade (A0-1 vs. A2-3) & 47 vs. 44 & \\
\hline ISGs (Mx, IFI44, IFIT1) & 3.3 & $(0.6-17.3)$ \\
\hline \multicolumn{3}{|l|}{ Laboratory parameters } \\
\hline HCV-RNA (KIU/ml) & 2000 & $(126-5000)$ \\
\hline BMl $\left(\mathrm{kg} / \mathrm{m}^{2}\right)$ & 23.8 & $(16.2-40.6)$ \\
\hline AST (IU/L) & 56 & $(20-283)$ \\
\hline ALT (IU/L) & 71 & $(16-376)$ \\
\hline V-GTP (IU/L) & 58 & $(4-392)$ \\
\hline WBC $\left(/ \mathrm{mm}^{3}\right)$ & 4500 & $(2100-11100)$ \\
\hline $\mathrm{Hb}(\mathrm{g} / \mathrm{dl})$ & 14.3 & $(11.2-17.2)$ \\
\hline $\operatorname{PLT}\left(\times 10^{4} / \mathrm{mm}^{3}\right)$ & 15.6 & $(6.6-39.4)$ \\
\hline $\mathrm{TG}(\mathrm{mg} / \mathrm{dl})$ & 109 & $(30-303)$ \\
\hline T-Chol (mg/dl) & 171 & (114-237) \\
\hline LDL-Chol (mg/dl) & 79 & $(42-123)$ \\
\hline HDL-Chol (mg/dl) & 44 & $(18-77)$ \\
\hline FBS (mg/dl) & 97 & $(59-291)$ \\
\hline Insulin $(\mu \mathrm{U} / \mathrm{ml})$ & 6.7 & $(0.7-23.2)$ \\
\hline HOMA-IR & 1.1 & $(0.3-11.7)$ \\
\hline
\end{tabular}

Viral factors

ISDR mutations $\leqq 1$ vs. $\geqq 2 \quad 61$ vs. 29

Treatment factors

Total dose administered

Peg-IFN $(\mu / \mathrm{kg})$

$\operatorname{RBV}(\mathrm{mg} / \mathrm{kg})$

Achieved administration rate

$3840 \quad(1500-7200)$

$202 \quad(26-336)$

$\begin{array}{lc}\text { Peg-IFN (\%) } & \\ \geqq 80 \% & 59(65 \%) \\ <80 \% & 32(35 \%) \\ \text { RBV (\%) } & \\ \geqq 80 \% & 54(59 \%) \\ <80 \% & 37(41 \%) \\ <\text { ievement of EVR } & 49 / 90(54 \%)\end{array}$

BMI, body mass index; AST, aspartate aminotransferase

ALT, alanine aminotransferase; $y$-GTP, gamma-glutamyl transpeptidase WBC; leukocytes, $\mathrm{Hb}$; hemoglobin, PLT; platelets, TG; triglycerides T-chol, total cholesterol; LDL-chol, low density lipoprotein cholesterol HDL-chol, high density lipoprotein cholesterol; FBS, fasting blood sugar 
Supplemental Table 4

Pairwise comparison of the expression of 15 ISGs in 168 patients

\begin{tabular}{|c|c|c|c|c|c|c|c|c|c|c|c|c|c|c|c|}
\hline & $M X$ & OAS3 & IFI44 & IFI44L & OAS2 & USP18 & RSAD2 & IFIT1 & $\mathrm{IFIH} 1$ & XAF1 & CMPK2 & EPSTI1 & HERC6 & PARP9 & PLSCR1 \\
\hline \multicolumn{16}{|l|}{$\overline{\mathrm{MX}}$} \\
\hline OAS3 & 0.95 & & & & & & & & & & & & & & \\
\hline IFI44 & 0.83 & 0.83 & & & & & & & & & & & & & \\
\hline IFI44L & 0.88 & 0.88 & 0.90 & & & & & & & & & & & & \\
\hline OAS2 & 0.82 & 0.83 & 0.90 & 0.94 & & & & & & & & & & & \\
\hline USP18 & 0.85 & 0.84 & 0.93 & 0.94 & 0.94 & & & & & & & & & & \\
\hline RSAD2 & 0.89 & 0.89 & 0.92 & 0.96 & 0.92 & 0.95 & & & & & & & & & \\
\hline IFIT1 & 0.92 & 0.89 & 0.85 & 0.90 & 0.84 & 0.88 & 0.93 & & & & & & & & \\
\hline $\mathrm{IFIH} 1$ & 0.82 & 0.85 & 0.92 & 0.92 & 0.92 & 0.92 & 0.93 & 0.87 & & & & & & & \\
\hline XAF1 & 0.81 & 0.79 & 0.88 & 0.89 & 0.91 & 0.88 & 0.90 & 0.82 & 0.89 & & & & & & \\
\hline CMPK2 & 0.93 & 0.92 & 0.88 & 0.94 & 0.89 & 0.92 & 0.96 & 0.92 & 0.90 & 0.86 & & & & & \\
\hline EPSTI1 & 0.83 & 0.85 & 0.89 & 0.90 & 0.92 & 0.90 & 0.91 & 0.84 & 0.91 & 0.87 & 0.90 & & & & \\
\hline HERC6 & 0.88 & 0.87 & 0.93 & 0.95 & 0.94 & 0.94 & 0.96 & 0.89 & 0.93 & 0.91 & 0.95 & 0.92 & & & \\
\hline PARP9 & 0.78 & 0.80 & 0.62 & 0.66 & 0.61 & 0.62 & 0.67 & 0.72 & 0.68 & 0.62 & 0.74 & 0.64 & 0.66 & & \\
\hline PLSCR1 & 0.79 & 0.83 & 0.80 & 0.84 & 0.83 & 0.80 & 0.82 & 0.78 & 0.84 & 0.77 & 0.82 & 0.81 & 0.84 & 0.66 & \\
\hline $\mathrm{MX}+\mathrm{IFI44+IFIT1}$ & 0.96 & 0.93 & 0.94 & 0.94 & 0.89 & 0.93 & 0.96 & 0.97 & 0.91 & 0.87 & 0.95 & 0.90 & 0.94 & 0.74 & 0.83 \\
\hline
\end{tabular}

Pearson's correlation coefficient is shown in black bold if the value is more than 0.9 and shown in red bold if the value is less than 0.8 . 
Supplemental Table 5

Sensitivity, specificity, and positive and negative predictive values of 15 ISGs on the likelihood of achieving SVR+TR.

\begin{tabular}{|c|c|c|c|c|c|}
\hline & Cut off & Sensitivity & Specificity & PPV & NPV \\
\hline MX+IFI44+IFIT1 & 3.5 & $\begin{array}{c}0.82 \\
103 / 125\end{array}$ & $\begin{array}{l}0.72 \\
31 / 43\end{array}$ & $\begin{array}{c}0.90 \\
103 / 115\end{array}$ & $\begin{array}{l}0.58 \\
31 / 53\end{array}$ \\
\hline$M X$ & 3.5 & $\begin{array}{c}0.80 \\
99 / 123\end{array}$ & $\begin{array}{l}0.67 \\
28 / 42\end{array}$ & $\begin{array}{c}0.88 \\
99 / 113\end{array}$ & $\begin{array}{l}0.54 \\
28 / 52\end{array}$ \\
\hline OAS3 & 1.5 & $\begin{array}{c}0.74 \\
91 / 123\end{array}$ & $\begin{array}{l}0.71 \\
29 / 41\end{array}$ & $\begin{array}{c}0.88 \\
91 / 103\end{array}$ & $\begin{array}{l}0.48 \\
29 / 61\end{array}$ \\
\hline IFI44 & 3.5 & $\begin{array}{c}0.78 \\
91 / 117\end{array}$ & $\begin{array}{l}0.71 \\
30 / 41\end{array}$ & $\begin{array}{c}0.88 \\
91 / 103\end{array}$ & $\begin{array}{l}0.54 \\
30 / 56\end{array}$ \\
\hline IFI44L & 1.5 & $\begin{array}{c}0.80 \\
98 / 123\end{array}$ & $\begin{array}{l}0.68 \\
28 / 41\end{array}$ & $\begin{array}{c}0.88 \\
98 / 111\end{array}$ & $\begin{array}{l}0.53 \\
28 / 53\end{array}$ \\
\hline OAS2 & 1.5 & $\begin{array}{c}0.74 \\
91 / 123\end{array}$ & $\begin{array}{l}0.73 \\
30 / 41\end{array}$ & $\begin{array}{c}0.89 \\
91 / 102\end{array}$ & $\begin{array}{l}0.48 \\
30 / 60\end{array}$ \\
\hline USP18 & 1.5 & $\begin{array}{c}0.80 \\
99 / 123\end{array}$ & $\begin{array}{l}0.68 \\
28 / 41\end{array}$ & $\begin{array}{c}0.88 \\
99 / 112\end{array}$ & $\begin{array}{l}0.54 \\
28 / 52\end{array}$ \\
\hline RSAD2 & 1.5 & $\begin{array}{c}0.77 \\
99 / 129\end{array}$ & $\begin{array}{l}0.73 \\
30 / 41\end{array}$ & $\begin{array}{c}0.90 \\
99 / 110\end{array}$ & $\begin{array}{l}0.50 \\
30 / 60\end{array}$ \\
\hline IFIT1 & 3.5 & $\begin{array}{c}0.80 \\
99 / 123\end{array}$ & $\begin{array}{l}0.71 \\
30 / 42\end{array}$ & $\begin{array}{c}0.89 \\
99 / 111\end{array}$ & $\begin{array}{l}0.56 \\
30 / 54\end{array}$ \\
\hline IFIH1 & 1.5 & $\begin{array}{c}0.81 \\
100 / 123\end{array}$ & $\begin{array}{l}0.61 \\
25 / 41\end{array}$ & $\begin{array}{c}0.86 \\
100 / 116\end{array}$ & $\begin{array}{l}0.52 \\
25 / 48\end{array}$ \\
\hline XAF1 & 2 & $\begin{array}{c}0.73 \\
90 / 123\end{array}$ & $\begin{array}{l}0.78 \\
32 / 41\end{array}$ & $\begin{array}{l}0.91 \\
90 / 99\end{array}$ & $\begin{array}{l}0.49 \\
32 / 65\end{array}$ \\
\hline CMPK2 & 2 & $\begin{array}{c}0.75 \\
92 / 123\end{array}$ & $\begin{array}{l}0.71 \\
29 / 41\end{array}$ & $\begin{array}{c}0.88 \\
92 / 104\end{array}$ & $\begin{array}{l}0.48 \\
29 / 60\end{array}$ \\
\hline EPSTI1 & 2 & $\begin{array}{c}0.72 \\
88 / 123\end{array}$ & $\begin{array}{l}0.78 \\
32 / 41\end{array}$ & $\begin{array}{l}0.91 \\
88 / 97\end{array}$ & $\begin{array}{l}0.48 \\
32 / 67\end{array}$ \\
\hline HERC6 & 1.5 & $\begin{array}{c}0.78 \\
96 / 123\end{array}$ & $\begin{array}{l}0.76 \\
31 / 40\end{array}$ & $\begin{array}{c}0.91 \\
96 / 106\end{array}$ & $\begin{array}{l}0.53 \\
31 / 58\end{array}$ \\
\hline PARP9 & 2 & $\begin{array}{c}0.90 \\
111 / 123\end{array}$ & $\begin{array}{l}0.44 \\
18 / 41\end{array}$ & $\begin{array}{c}0.83 \\
111 / 134\end{array}$ & $\begin{array}{l}0.60 \\
18 / 30\end{array}$ \\
\hline PLSCR1 & 1.3 & $\begin{array}{c}0.85 \\
105 / 123\end{array}$ & $\begin{array}{l}0.51 \\
21 / 41\end{array}$ & $\begin{array}{c}0.84 \\
105 / 125\end{array}$ & $\begin{array}{l}0.54 \\
21 / 39\end{array}$ \\
\hline
\end{tabular}


Supplemental Table 6

Comparison of multivariate logistic regression models for SVR+TR and NR using ISGs and/or IL28B genotype as variables

\begin{tabular}{|c|c|c|c|c|c|c|}
\hline & Variables & Category & Odds $(95 \% \mathrm{Cl})$ & $p$-value & $\mathrm{AIC}$ & AUC \\
\hline \multirow{4}{*}{$\begin{array}{l}\text { Multivariate model with ISGs } \\
\qquad(\mathrm{n}=91)\end{array}$} & ISGs & $<3.5$ vs. $\geqq 3.5$ & $25.1(6.03-176)$ & $<0.001$ & \multirow{4}{*}{78} & \multirow{4}{*}{0.87} \\
\hline & BMI & $<25$ vs. $\geqq 25 \mathrm{~kg} / \mathrm{m}^{2}$ & $4.13(0.89-29.9)$ & 0.071 & & \\
\hline & ISDR mutations & $\leqq 1$ vs. $\geqq 2$ & $3.07(0.81-14.1)$ & 0.102 & & \\
\hline & F stage & F1-2 vs. F3-4 & $2.48(0.73-9.25)$ & 0.146 & & \\
\hline \multirow{4}{*}{$\begin{array}{l}\text { Multivariate model with IL28B } \\
\qquad(\mathrm{n}=91)\end{array}$} & IL28B & Major vs. Minor & $35.2(8.19-259)$ & $<0.001$ & \multirow{4}{*}{74} & \multirow{4}{*}{0.89} \\
\hline & F stage & F1-2 vs. F3-4 & $3.31(0.90-14.3)$ & 0.070 & & \\
\hline & BMI & $<25$ vs. $\geqq 25 \mathrm{~kg} / \mathrm{m}^{2}$ & $4.01(0.85-29.3)$ & 0.081 & & \\
\hline & ISDR mutations & $\leqq 1$ vs. $\geqq 2$ & $2.39(0.50-14.1)$ & 0.280 & & \\
\hline \multirow{5}{*}{$\begin{array}{l}\text { Multivariate model with ISGs and IL28B } \\
\qquad(\mathrm{n}=91)\end{array}$} & IL28B & Major vs. Minor & 19.5 (3.69-176) & $<0.001$ & \multirow{5}{*}{67} & \multirow{5}{*}{0.92} \\
\hline & ISGs & $<3.5$ vs. $\geqq 3.5$ & $11.3(2.12-90.9)$ & 0.004 & & \\
\hline & $\mathrm{BMI}$ & $<25$ vs. $\geqq 25 \mathrm{~kg} / \mathrm{m}^{2}$ & $12.2(1.82-163)$ & 0.008 & & \\
\hline & F stage & F1-2 vs. F3-4 & $3.14(0.79-15.4)$ & 0.106 & & \\
\hline & ISDR mutations & $\leqq 1$ vs. $\geqq 2$ & $2.76(0.55-18.0)$ & 0.224 & & \\
\hline
\end{tabular}

$\mathrm{Cl}$, confidence interval

AIC, Akaike's information criterion; $A I C=-2 \mathrm{ln} L+2 k$ ( $L=$ maximum likelihood, $k=$ the number of fitted parameters in the model)

$A \cup C$, area under the curve of a receiver operating characteristic 


\section{Supplemental Fig 1}

A
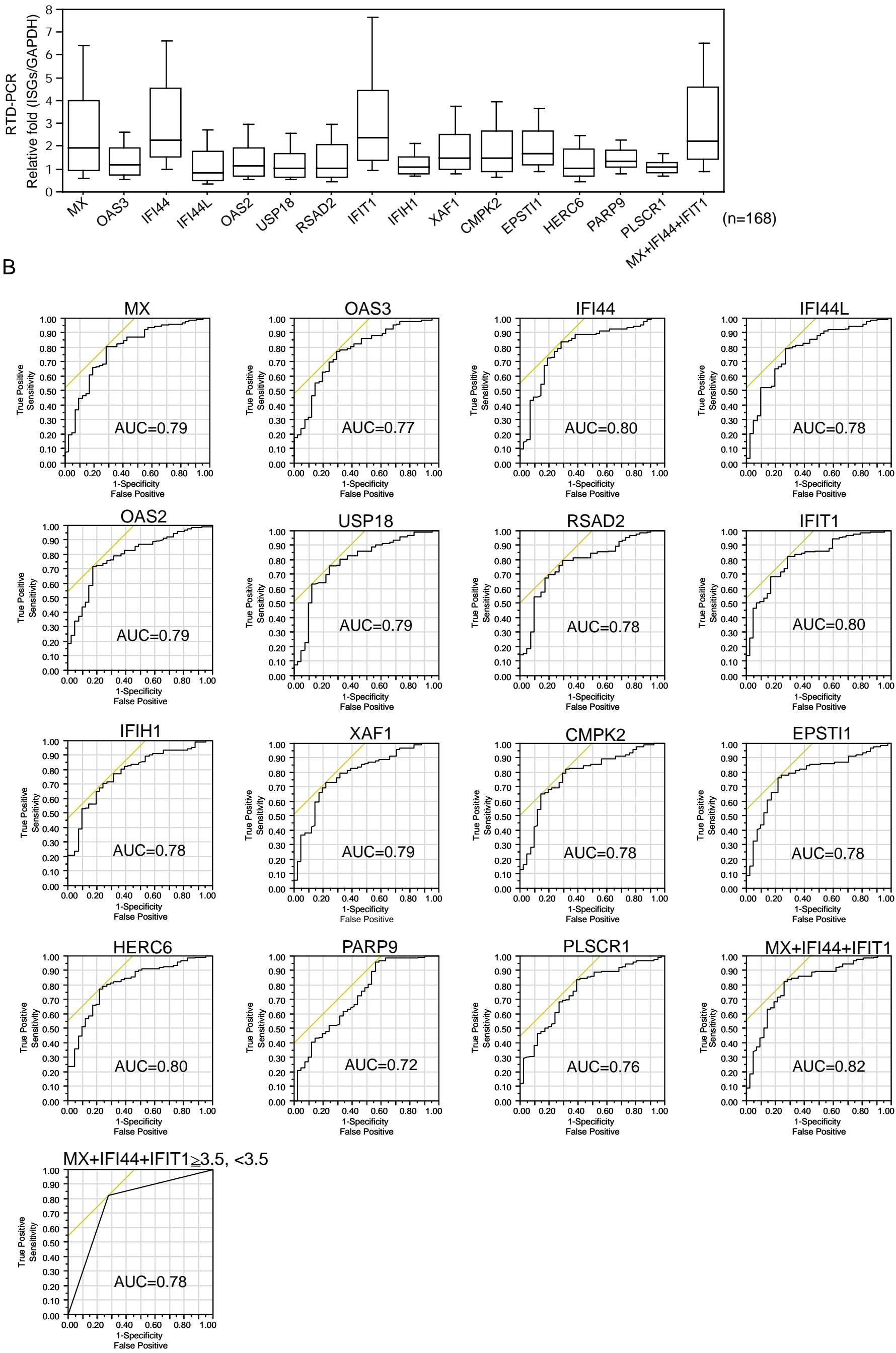
Supplemental Fig. 2

$S V R+T R$

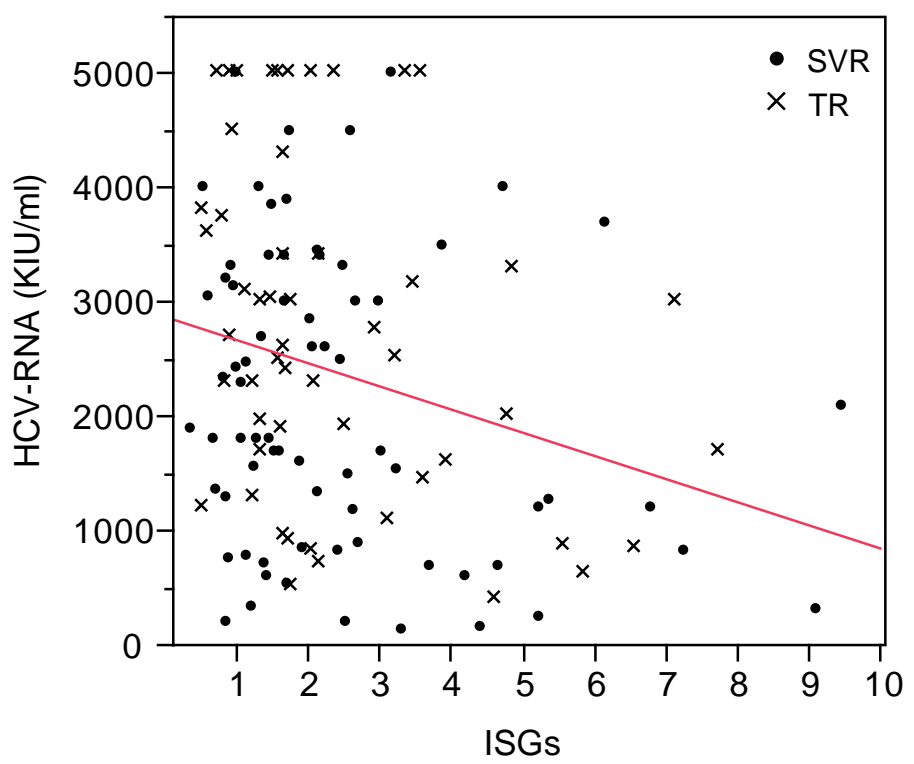

NR

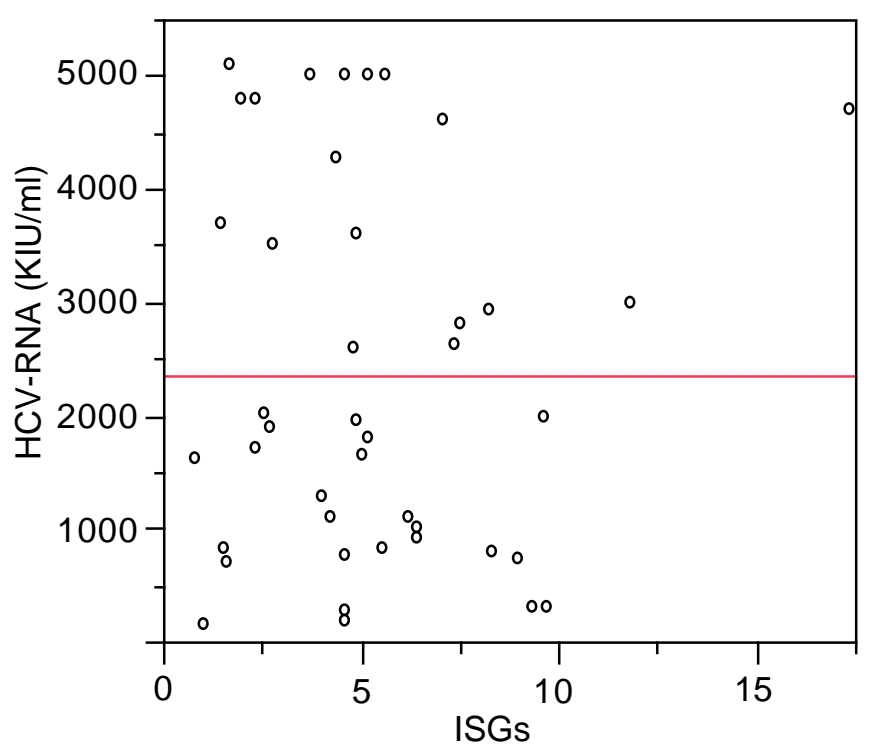




\section{Supplemental Fig. 3}

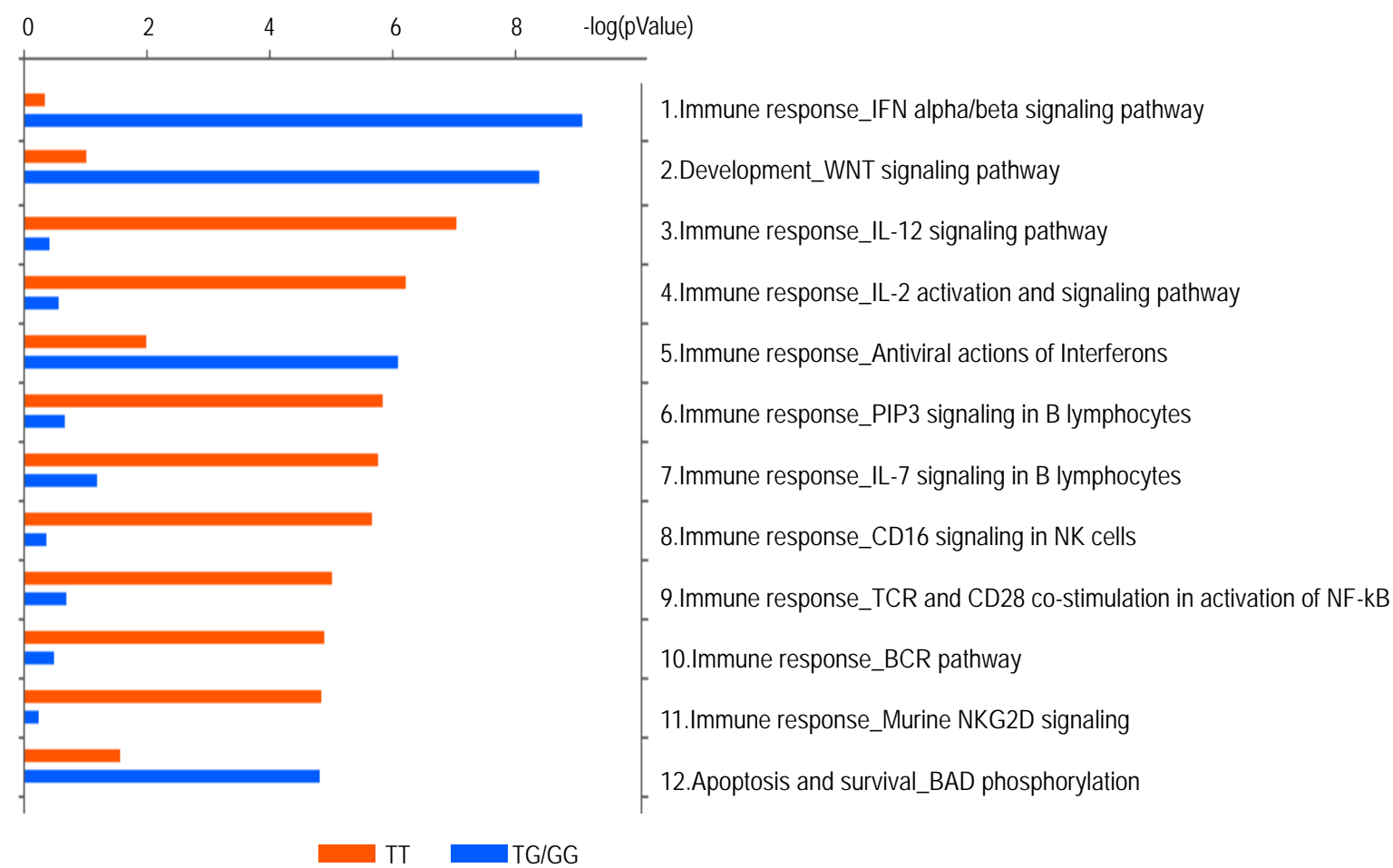

